\title{
Hypersensitivity to mGluR5 and ERK1/2 Leads to Excessive Protein Synthesis in the Hippocampus of a Mouse Model of Fragile X Syndrome
}

\author{
Emily K. Osterweil, Dilja D. Krueger, Kimberly Reinhold, and Mark F. Bear \\ Department of Brain and Cognitive Sciences, Howard Hughes Medical Institute, Picower Institute for Learning and Memory, Massachusetts Institute of \\ Technology, Cambridge, Massachusetts 02139
}

\begin{abstract}
Fragile X syndrome (FXS) is caused by loss of the FMR1 gene product FMRP (fragile X mental retardation protein), a repressor of mRNA translation. According to the metabotropic glutamate receptor (mGluR) theory of FXS, excessive protein synthesis downstream of mGluR5 activation causes the synaptic pathophysiology that underlies multiple aspects of FXS. Here, we use an in vitro assay of protein synthesis in the hippocampus of male Fmr1 knock-out (KO) mice to explore the molecular mechanisms involved in this core biochemical phenotype under conditions where aberrant synaptic physiology has been observed. We find that elevated basal protein synthesis in Fmr1 KO mice is selectively reduced to wild-type levels by acute inhibition of mGluR 5 or ERK1/2, but not by inhibition of mTOR (mammalian target of rapamycin). The mGluR5-ERK1/2 pathway is not constitutively overactive in the Fmr1 K0, however, suggesting that mRNA translation is hypersensitive to basal ERK1/2 activation in the absence of FMRP. We find that hypersensitivity to ERK1/2 pathway activation also contributes to audiogenic seizure susceptibility in the $F m r 1 \mathrm{KO}$. These results suggest that the ERK1/2 pathway, and other neurotransmitter systems that stimulate protein synthesis via ERK1/2, represent additional therapeutic targets for FXS.
\end{abstract}

\section{Introduction}

Fragile X syndrome (FXS) is caused by the loss of the FMR1 gene product FMRP (fragile X mental retardation protein) (Verkerk et al., 1991). Converging lines of evidence suggest that FMRP represses mRNA translation in neurons and that cerebral protein synthesis is elevated in the absence of FMRP (Laggerbauer et al., 2001; Li et al., 2001; Huber et al., 2002; Aschrafi et al., 2005; Qin et al., 2005; Dölen et al., 2007; Bolduc et al., 2008). Group 1 (Gp1) metabotropic glutamate receptors (mGluR1 and mGluR5) stimulate mRNA translation at synapses (Weiler and Greenough, 1993; Weiler et al., 1997) and many lasting physiological consequences of Gp1 mGluR activation require rapid synaptic protein synthesis (Merlin et al., 1998; Huber et al., 2000; Raymond et al., 2000; Karachot et al., 2001; Vanderklish and Edelman, 2002; Banko et al., 2006). Based initially on the finding that mGluRdependent long-term synaptic depression (mGluR-LTD) is exaggerated in the hippocampus of Fmr1 knock-out (KO) mice (Huber et al., 2002), the proposal was made that many of the symptoms of FXS might plausibly be explained by excessive protein synthesis downstream of Gp1 mGluR activation (Bear et al.,

Received July 26, 2010; revised Aug. 20, 2010; accepted Sept. 23, 2010.

This work was supported in part by grants from FRAXA, the National Institute of Mental Health, the National Institute of Child Health and Human Development, the Simons Foundation, and the Hilibrand Foundation. For excellent technical support and helpful discussions we thank the following: Kathleen "Barbara" Oram, Suzanne Meagher, Erik Sklar, Arnold Heynen, Genevieve Conley, Cornelia Hall, Eugenia Gisin, Stephanie Lacy, Charlotte Yang, Lena Khibnik, Monica Linden, Rahmat Muhammad, Bridget Dolan, Gül Dölen, and Gordon Smith.

Correspondence should be addressed to Mark F. Bear, The Picower Institute for Learning and Memory, MIT 46-3301, 43 Vassar Street, Cambridge, MA 02139. E-mail: mbear@mit.edu.

DOI:10.1523/JNEUROSCI.3888-10.2010

Copyright $\odot 2010$ the authors $\quad$ 0270-6474/10/3015616-12\$15.00/0
2004). The prediction that multiple aspects of fragile $X$ can be corrected by reducing or inhibiting mGluR5 has been confirmed in numerous studies in several species (for review, see Dölen and Bear, 2008).

Although it is now clear that mGluR5 participates in the pathogenesis of FXS, at least in animal models, it is still poorly understood how Gp1 mGluRs trigger protein synthesis and how this process is altered in the absence of FMRP to disrupt synaptic function. Several studies have examined this issue in the hippocampus and cortex, but no clear consensus has emerged (Weiler et al., 2004; Hou et al., 2006; Muddashetty et al., 2007; Kim et al., 2008; Park et al., 2008; Ronesi and Huber, 2008; Sharma et al., 2010). One source of confusion may be that proxy measures of protein synthesis, such as mGluR-LTD or phosphorylation of signaling molecules, have been used in intact hippocampal slice preparations, whereas metabolic labeling experiments have been performed in synaptoneurosome preparations of cortex that are not easily related to altered hippocampal synaptic plasticity.

In the current study, we reexamine the question of how protein synthesis is elevated in the Fmrl KO using a metabolic labeling approach in hippocampal slices maintained under the same conditions that revealed altered mGluR-dependent synaptic plasticity in previous studies from our laboratory (Huber et al., 2002; Auerbach and Bear, 2010). A strong rationale for taking this approach is that slice has been shown to accurately reproduce the in vivo phenotype of elevated basal protein synthesis in the Fmrl $\mathrm{KO}$ hippocampus (cf. Qin et al., 2005; Dölen et al., 2007). Further, in addition to reproducing this core biochemical phenotype, the slice has the advantage that it enables pharmacological and biochemical access that is not possible in vivo. Our data suggest that 
elevated protein synthesis in the Fmr1 KO is due to saturation of mRNA translation downstream of the MAP kinase ERK1/2 which is basally activated by mGluR5.

\section{Materials and Methods}

Mice. Fmr1 KO (Jackson Labs) and wild type littermates were kept on the C57BL/6J background, group housed, and maintained in a $12 \mathrm{~h}$ light/ dark cycle. All animals were treated in accordance with NIH and MIT guidelines. All experiments were performed blind to genotype. On each day of slice experimentation, 4 animals from each genotype were killed in an interleaved fashion and slices were prepared as rapidly as possible ( $\leq 5$ $\mathrm{min}$ ) as described below. This procedure yielded yoked, same-day controls for genotype and drug treatments.

Drugs. ( $R, S)$-3,5-Dihydroxyphenylglycine (DHPG), 2-methyl-6-(phenylethynyl)pyridine hydrochloride (MPEP), 1,4-diamino-2,3-dicyano1,4-bis[2-aminophenylthio]butadiene (U0126), actinomycin D (ActD), and $\alpha$-[amino[(4-aminophenyl)thio]methylene]-2-(trifluoromethyl) benzeneacetonitrile (SL 327) were obtained from Tocris Bioscience. DHPG and MPEP stocks were freshly prepared in $\mathrm{ddH}_{2} \mathrm{O}$ on the day of the experiment. ActD stock was prepared in ACSF $+0.5 \%$ DMSO and kept at $-20^{\circ} \mathrm{C}$. Anti-TrkB (R\&D Systems), BDNF (Peprotech), insulin (Sigma), rapamycin (EMD Biosciences), cycloheximide (EMD Biosciences), U0126, and SL 327 were reconstituted according to manufacturer's instructions and either used immediately or stored at $-20^{\circ} \mathrm{C}$. For all slice experiments, the final concentration of DMSO was $<0.1 \%$.

Metabolic labeling. Juvenile [postnatal day 25 (P25)-P30] male littermate wild-type (WT) and Fmrl KO mice were given an overdose of Nembutal, and the hippocampus was rapidly dissected into ice-cold artificial CSF (ACSF) (in mm: $124 \mathrm{NaCl}, 3 \mathrm{KCl}, 1.25 \mathrm{NaH}_{2} \mathrm{PO}_{4}, 26$ $\mathrm{NaHCO}_{3}, 10$ dextrose, $1 \mathrm{MgCl}_{2}, 2 \mathrm{CaCl}_{2}$, saturated with $95 \% \mathrm{O}_{2}$ and $5 \%$ $\mathrm{CO}_{2}$ ). Slices (500 $\mu \mathrm{m}$ thick) were prepared using a Stoelting Tissue Slicer and transferred into $32.5^{\circ} \mathrm{C}$ ACSF (saturated with $95 \% \mathrm{O}_{2}$ and $5 \% \mathrm{CO}_{2}$ ) within 5 min. Unless indicated otherwise, slices were incubated in ACSF undisturbed for 3.5-4 h to allow for recovery of protein synthesis (Sajikumar et al., 2005). ActD $(25 \mu \mathrm{M})$ was then added to the recovery chamber for $30 \mathrm{~min}$ to inhibit transcription. For DHPG $(100 \mu \mathrm{M})$ and whole-slice MPEP $(50 \mu \mathrm{M})$ experiments, slices were incubated in 10 $\mu \mathrm{Ci} / \mathrm{ml}{ }^{35} \mathrm{~S}$-Met/Cys (express protein labeling mix, PerkinElmer) \pm drug for $5 \mathrm{~min}$, and transferred to fresh ACSF with $10 \mu \mathrm{Ci} / \mathrm{ml}{ }^{35} \mathrm{~S}$-Met/ Cys for another $25 \mathrm{~min}$ to measure protein synthesis. For cycloheximide (60 $\mu \mathrm{M}$; performed in WT), CA1 MPEP $(10 \mu \mathrm{M})$, U0126 (5 $\mu \mathrm{M})$, and rapamycin $(20 \mathrm{nM})$ experiments, slices were incubated \pm drug during ActD exposure (30 min), and transferred to fresh ACSF with $10 \mu \mathrm{Ci} / \mathrm{ml}$ ${ }^{35} \mathrm{~S}$-Met/Cys \pm drug for another $30 \mathrm{~min}$. For TrkB activation experiments, slices were incubated $\pm 1 \mu \mathrm{g} / \mathrm{ml}$ anti-TrkB for $30 \mathrm{~min}$, then $25 \mu \mathrm{M}$ ActD $\pm 1 \mu \mathrm{g} / \mathrm{ml}$ anti-TrkB for $30 \mathrm{~min}$, and protein synthesis measured with $10 \mu \mathrm{Ci} / \mathrm{ml}{ }^{35} \mathrm{~S}$-Met/Cys $\pm 1 \mu \mathrm{g} / \mathrm{ml}$ anti-TrkB for $1 \mathrm{~h}$. After labeling, slices were either snap frozen in liquid nitrogen or processed immediately.

With the exception of CA1 MPEP experiments, slices were homogenized in ice-cold homogenization buffer (10 mM HEPES pH 7.4, 2 mм EDTA, 2 mm EGTA, 1\% Triton X-100, protease inhibitors (cocktail III, EMD Biosciences), and phosphatase inhibitors (cocktails I + II, EMD Biosciences), and incubated in trichloroacetic acid (TCA; $10 \%$ final) for $10 \mathrm{~min}$ on ice to precipitate radiolabeled proteins. Samples were then spun at $21,000 \times g$ for $10 \mathrm{~min}$, and the pellet was washed with ice-cold $\mathrm{ddH}_{2} \mathrm{O}$ and resuspended in $1 \mathrm{~N} \mathrm{NaOH}$ until dissolved. After adjustment to a neutral $\mathrm{pH}$ with $\mathrm{HCl}$, triplicate aliquots of each sample were added to scintillation cocktail (HiSafe II, PerkinElmer) and read with a scintillation counter, and also subjected to a protein concentration assay (Bio-Rad). Averaged triplicate cpm values were divided by protein concentrations, resulting in cpm per $\mu \mathrm{g}$ protein. To control for daily variation in incorporation rate, the values obtained on each day were normalized to the ${ }^{35} \mathrm{~S}$-Met/Cys ACSF used for incubation, and the average incorporation of all slices analyzed in that experiment, as described by Lipton and Raley-Susman (1999).

For CA1-MPEP experiments, slices were briefly thawed and CA1 regions were dissected. To obtain autoradiographs, aliquots of homogenized CA1 were taken before TCA precipitation and boiled in Laemmli sample buffer. Samples were then resolved on SDS polyacrylamide gels, transferred to nitrocellulose, and stained for total protein (Memcode staining kit, Pierce). Blots were exposed to a PhosphorImager screen for 24-72 h, and the screen was read with a PhosphorImager (Fujifilm). To quantify autoradiographs and Memcode-stained blots, a line-scan of each lane was measured and quantified using the gel analyzer tool in ImageJ. Protein synthesis was calculated by normalizing data from autoradiographs to Memcode staining data obtained from the same lanes.

Acute stimulation. Slices were prepared and allowed to recover as for metabolic labeling, incubated in $100 \mu \mathrm{M}$ DHPG for exactly $5 \mathrm{~min}$ or $1 \mu \mathrm{M}$ insulin for $10 \mathrm{~min}$, then snap frozen in liquid nitrogen. Frozen slices were either immediately homogenized in Laemmli sample buffer containing phosphatase inhibitors, or briefly thawed and microdissected in homogenization buffer with protease and phosphatase inhibitors (minus detergent). Microdissected regions were homogenized in sample buffer containing phosphatase inhibitors immediately following dissection.

Synaptoneurosomes. Synaptoneurosomes were isolated from sets of 4 slices essentially as described previously (Chen and Bear, 2007). Slices were homogenized on ice using $2 \mathrm{ml}$ glass Dounce homogenizers (Wheaton), passed through $2 \times 105 \mu \mathrm{m}$ meshes, followed by $1 \times 5 \mu \mathrm{m}$ mesh, and the resulting samples spun at $1,000 \times g$ for 10 min at $4^{\circ} \mathrm{C}$. Pellets were washed, spun at $1000 \times g$, and processed for SDS-PAGE.

Immunoblotting. Samples were boiled in Laemmli sample buffer, resolved on SDS polyacrylamide gels, transferred to nitrocellulose, and stained for total protein. Immunoblotting was performed with the following primary antibodies: from Cell Signaling Technology, p-ERK1/2 (Thr202/Tyr204), ERK1/2, p-p38 (Thr180/Tyr182), p38, p-Akt (Ser473), p-mTOR (mammalian target of rapamycin) (Ser2448), mTOR, p-PTEN (Ser380/Thr382/383), PTEN, p-p70S6K (Thr389), p70S6K, p-S6 (Ser235/236), S6 p-Trk (Tyr490), and GAPDH; other: TrkB (BD Biosciences) and $\alpha$ - $\mathrm{Ca}^{2+} /$ calmodulin-dependent kinase kinase II ( $\alpha$-CaMKII) (Sigma). After incubation in primary antibody overnight at $4^{\circ} \mathrm{C}$, immunoblots were either incubated with fluorophoreconjugated secondary antibodies and imaged with the Odyssey imaging system (LiCor Biosciences), or incubated with HRP-conjugated secondary antibodies (GE Healthcare), developed with ECL plus (GE Healthcare) and exposed to film. Densitometry was performed on scanned blot films or LiCor images using Quantity One software (Bio-Rad). Data were expressed as the value of the phosphorylation signal divided by the value of the total protein signal in the same lane. To correct for blot-to-blot variance, each signal was normalized to the average signal of all lanes on the same blot. All gels were loaded and analyzed blind to genotype and treatment.

Fresh dissections. WT and Fmr1 KO (P25-P32) male littermates were killed by rapid decapitation, and hippocampi were rapidly dissected into ice-cold homogenization buffer. Tissue was homogenized on ice using 2 $\mathrm{ml}$ glass Dounce homogenizers, and processed for SDS-PAGE.

Immunoprecipitation. Hippocampal slices (5-8 per animal) were prepared as described above from WT and Fmrl KO mice and metabolically labeled with $50 \mu \mathrm{Ci} / \mathrm{ml}{ }^{35} \mathrm{~S}-\mathrm{Met} / \mathrm{Cys}$ for $1 \mathrm{~h}$ to ensure visualization of individual target proteins. Immunoprecipitation (IP) experiments were performed on yoked WT and Fmr1 KO slices essentially as described by Osterweil et al. (2005) and Kundel et al. (2009). Briefly, slices were homogenized in ice-cold homogenization buffer with $200 \mathrm{~mm} \mathrm{NaCl}$, spun at $2000 \times g$ for $5 \mathrm{~min}$, and the supernatant was adjusted to $400 \mathrm{~mm} \mathrm{NaCl}$. Samples were then spun at $16,000 \times g$ for $30 \mathrm{~min}$, precleared with $1 / 10$ volume protein A-Sepharose (GE Healthcare) for $1 \mathrm{~h}$ at $4^{\circ} \mathrm{C}$, and incubated with $10 \mu \mathrm{g} / \mathrm{ml}$ nonimmune mouse IgG (Santa Cruz Biotechnology), mouse anti-GAPDH (Millipore), or mouse anti- $\alpha$-CaMKII (Millipore) overnight at $4^{\circ} \mathrm{C}$. Samples were then incubated with $1 / 10$ volume protein A-Sepharose for $2 \mathrm{~h}$ at $4^{\circ} \mathrm{C}$, and the IPs were washed 5 times in $1 \mathrm{ml}$ of homogenization buffer with $400 \mathrm{~mm} \mathrm{NaCl}$. IPs were resuspended in an equal volume of Laemmli sample buffer, resolved on SDS polyacrylamide gels, transferred to nitrocellulose, and exposed to a PhosphorImager screen for 2-3 weeks. The same membranes were then immunoblotted for $\alpha$-CaMKII and GAPDH. For each sample, the ratio of ${ }^{35} \mathrm{~S}$-incorporated/total was calculated by dividing the density of the band seen by autoradiography to the density of the band seen by immu- 
noblot (in the same lane). Experiments were performed and analyzed blind to genotype.

TrkB stimulation. Hippocampal neurons were prepared from embryonic day 18 rat embryos as described previously (Krueger and Nairn, 2007), and cultured for $21 \mathrm{~d}$. Thirty minutes before stimulation, the medium was removed and replaced with $0.75 \mathrm{ml}$ of medium (50\% conditioned, $50 \%$ fresh) to control for volume. TrkB stimulation was performed with a $15 \mathrm{~min}$ incubation of vehicle or $1 \mu \mathrm{g} / \mathrm{ml}$ anti-TrkB, followed by application of vehicle or $100 \mathrm{ng} / \mathrm{ml}$ BDNF for $5 \mathrm{~min}$. Plates were then washed with ice-cold PBS, and cells were lysed in buffer containing 50 mm Tris, pH 7.4, 1 mm EDTA, 1 mm EGTA, 1\% SDS, protease inhibitors, and phosphatase inhibitors. Whole-cell lysates were processed for SDS-PAGE and immunoblotted.

Audiogenic seizures. Experiments were performed essentially as described previously (Dölen et al., 2007). Male WT and Fmr1 KO littermates (P18-P22) were injected intraperitoneally with SL $327(100 \mathrm{mg} /$ $\mathrm{kg}$; dose based on Zhong et al., 2009), rapamycin ( $6 \mathrm{mg} / \mathrm{kg}$; dose based on Ehninger et al., 2008 and Meikle et al., 2008) or an equal volume of vehicle (50\% DMSO in $\mathrm{ddH}_{2} \mathrm{O}$ for SL 327 experiments; $100 \%$ DMSO for rapamycin experiments), and returned to their home cage for $1 \mathrm{~h}$. Each testing session contained at least one set of vehicle-treated controls from each genotype. Mice were then transferred to a transparent plastic test chamber and, after at least $1 \mathrm{~min}$ of habituation, exposed to an alarm (modified personal alarm, $125 \mathrm{~dB}$ RadioShack model 49-1010 or $130 \mathrm{~dB}$ Samfe model SWPDAL-130, powered from a DC converter) for $2 \mathrm{~min}$. For each group, incidence of the following stages of audiogenic seizures (AGS) was calculated: wild running, clonic seizure, tonic seizure, and death. All mice were injected and scored blind to genotype.

Statistics. For AGS experiments, significance was determined using two-tailed Fisher's exact test (appropriate for analyzing nominal datasets). For recovery time course experiments, significance was determined using repeated-measures ANOVA, followed by post hoc two-tailed unpaired Student's $t$ tests. For all other experiments, outliers ( \pm 2 SDs from the mean) were removed, and significance between more than two groups was determined by two-way repeated measures mixed model ANOVA. If significant effects were found by ANOVA, post hoc analyses were performed to compare individual groups using two-tailed paired Student's $t$ tests. For datasets that contained only two groups, significance was determined by two-tailed paired Student's $t$ tests.

\section{Results}

Basal protein synthesis is elevated in the Fmr1 KO hippocampus The molecular mechanisms underlying dysfunctional protein synthesis in the Fmrl KO are largely unknown. To explore this question, we used an in vitro assay designed to measure protein synthesis in acute hippocampal slices. To directly relate our observations to the aberrant physiology seen in the Fmrl KO, we examined slices isolated from P25-P30 dorsal hippocampus, as this is when and where exaggerated mGluR- and protein synthesis-dependent LTD is observed (Huber et al., 2002). Slices were prepared from dorsal hippocampus, and immediately transferred to $32.5^{\circ} \mathrm{C}$ ACSF (see Materials and Methods). These slices were then exposed to ActD $(25 \mu \mathrm{M})$ for $30 \mathrm{~min}$ to prevent new transcription, and protein synthesis was measured over 30 min via incorporation of a ${ }^{35} \mathrm{~S}$-labeled methionine/cysteine mix $\left(10 \mu \mathrm{Ci} / \mathrm{ml}^{35} \mathrm{~S}\right.$-Met/Cys). To verify that our measurements accurately reflect global protein synthesis, slices were incubated \pm $60 \mu \mathrm{M}$ cycloheximide for $30 \mathrm{~min}$, and protein synthesis measured $\pm 60 \mu \mathrm{M}$ cycloheximide for an additional $30 \mathrm{~min}$. This experiment confirmed that exposure to cycloheximide, a potent inhibitor of mRNA translation, completely eliminates ${ }^{35} \mathrm{~S}$-Met/ Cys incorporation (supplemental Fig. S1, available at www. jneurosci.org as supplemental material).

A number of previous studies suggest that a long $(>2-4 \mathrm{~h})$ postslicing recovery period is necessary to achieve stability in metabolic function (i.e., ATP and creatine levels) (Whittingham et al., 1984), signaling cascades (Ho et al., 2004), dendritic spine density (Kirov et al., 1999), and protein synthesis-dependent synaptic plasticity (Huber et al., 2001; Sajikumar et al., 2005). We confirmed and extended this conclusion using our assay of basal protein synthesis in hippocampal slices. We found that optimal and stable protein synthesis recovers $4-6 \mathrm{~h}$ after preparing slices (protein synthesis expressed as percentage \pm SEM of $4 \mathrm{~h}$ value: $0.5 \mathrm{~h}, 76 \pm 7 \% ; 1 \mathrm{~h}, 72 \pm 8 \% ; 2 \mathrm{~h}, 88 \pm 9 \% ; 4 \mathrm{~h}, 100 \pm$ $8 \% ; 6$ h, $99 \pm 8 \%$; ANOVA time $p<0.05 ; n=10$; Fig. $1 A$ ). This observation is consistent with electrophysiological measurements of optimal protein synthesis-dependent synaptic plasticity in the hippocampus (Sajikumar et al., 2005), including optimal mGluRLTD (Huber et al., 2001). Therefore, for all experiments reported here, the hippocampus was allowed to recover for at least $4 \mathrm{~h}$ following slicing.

To examine whether protein synthesis is elevated in Fmrl KO hippocampus under conditions where exaggerated mGluR-LTD is observed, we performed metabolic labeling on juvenile, dorsal Fmr1 KO slices. Our results reveal a significant elevation of basal protein synthesis in Fmrl KO hippocampus compared with wild type (WT) controls (WT $100 \pm 3 \%$, KO $119 \pm 5 \%$; $t$ test $p<0.02$; $n=13$; Fig. $1 B$ ). The magnitude of this increase in protein synthesis is in quantitative agreement with in vivo measurements (Qin et al., 2005), and with our previous results in adult, ventral hippocampus (Dölen et al., 2007).

Autoradiographs of Fmr1 KO versus WT slices show an increased ${ }^{35} \mathrm{~S}$-Met/Cys incorporation into proteins of multiple molecular weights, which supports the proposal that FMRP functions as a rather general repressor of translation (Fig. 1B) (Laggerbauer et al., 2001; Li et al., 2001; Mazroui et al., 2002; Aschrafi et al., 2005). To confirm that our measurement of increased total protein synthesis reflects derepression of FMRPregulated translation, we performed IP experiments to isolate newly made $\alpha$-CaMKII, a validated target mRNA for FMRP (Brown et al., 2001; Zalfa et al., 2003; Ferrari et al., 2007; Muddashetty et al., 2007). $\alpha$-CaMKII was immunoprecipitated from WT and Fmrl KO slices that had been metabolically labeled with $50 \mu \mathrm{Ci} / \mathrm{ml}^{35} \mathrm{~S}$-Met/Cys for $1 \mathrm{~h}$ (see Materials and Methods). To ensure the efficacy of our IP experiments, we quantified the amount of $\alpha$-CaMKII (assessed by immunoblot) observed in anti- $\alpha$-CaMKII IPs versus IgG IPs from the same lysates (supplemental Fig. S2 A, available at www.jneurosci.org as supplemental material). Our results confirm that $\alpha$-CaMKII is significantly enriched in the anti- $\alpha$-CaMKII IPs from both WT and Fmr1 KO slices (WT IgG $100 \pm 12 \%$, WT CaMK $600 \pm 73 \%$, KO IgG $70 \pm$ $25 \%$, KO CaMK $544 \pm 45 \%$; $t$ test WT IgG vs $\mathrm{CaMK}^{*} p<0.002$, $t$ test $\mathrm{KO}$ IgG vs CaMK ${ }^{*} p<0.0001 ; n=6$ ) (supplemental Figure S2 A, available at www.jneurosci.org as supplemental material). To quantify newly translated protein, ${ }^{35}$ S-incorporated $\alpha$-CaMKII was measured by autoradiography, and normalized to total $\alpha$-CaMKII in the same IP (Fig. 1C). A comparison of these values in WT versus Fmrl KO reveals that $\alpha$-CaMKII is excessively translated in hippocampal slices from the Fmr1 KO (WT $100 \pm$ $12 \%$, KO $124 \pm 11 \%$; $t$ test ${ }^{*} p<04 ; n=6$; Fig. $1 D$ ). This increase in newly translated $\alpha$-CaMKII is similar in magnitude to the increase seen in total protein synthesis (Fig. 1B).

We also performed the same IP experiments for glyceraldehyde phosphate dehydrogenase (GAPDH), a non-FMRP target (Brown et al., 2001). Analysis of GAPDH levels confirmed a significant enrichment in anti-GAPDH IPs versus IgG IPs in both WT and Fmrl KO slices (WT IgG $100 \pm 19 \%$, WT GAPDH $1832 \pm 268 \%$, KO IgG $99 \pm 26 \%$, KO GAPDH $2250 \pm 314 \%$; $t$ test WT IgG vs $\mathrm{GAPDH}^{*} p<0.003, t$ test KO IgG vs GAPDH 
A
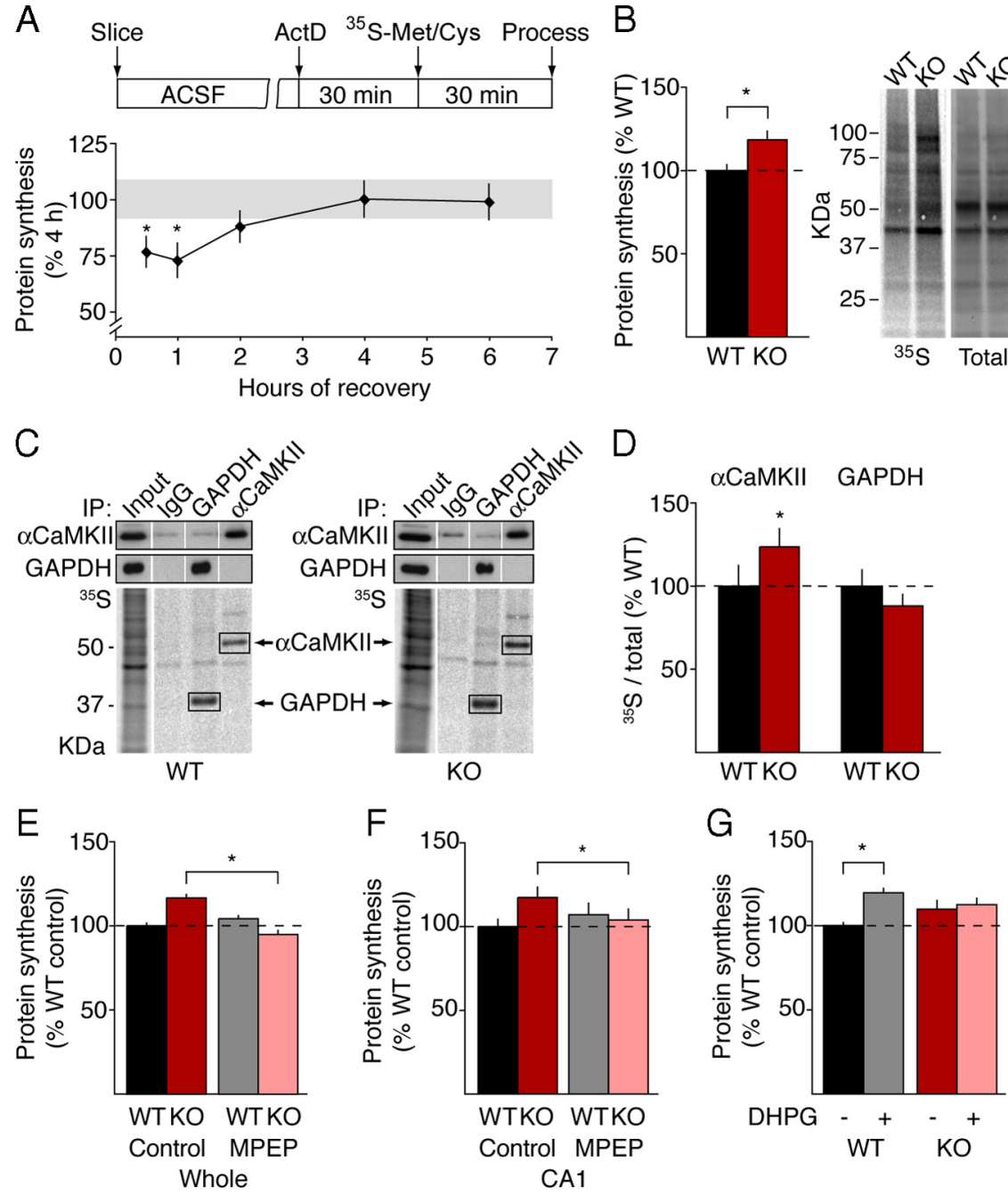

Figure 1. Exaggerated protein synthesis in the $F m r 1 \mathrm{KO}$ is ameliorated by mGluR5 antagonism and mimicked by mGluR activation in WT. $A$, Schematic illustrates experimental timeline: hippocampal slices were recovered in ACSF, incubated with $25 \mu \mathrm{M}$ ActD for $30 \mathrm{~min}$, then protein synthesis was measured with $10 \mu \mathrm{Ci} / \mathrm{ml}^{35} \mathrm{~S}-\mathrm{Met} / \mathrm{Cys}$ for $30 \mathrm{~min}$. To measure the effect of after slice recovery time on protein synthesis, slices were incubated in ACSF for $0,0.5,1.5,3.5$, or $5.5 \mathrm{~h}$ before exposure to ActD and metabolic labeling. Quantification of multiple experiments showed that a $4 \mathrm{~h}$ postslice recovery time yields maximal protein synthesis, which is stable for at least another $2 \mathrm{~h}$ (ANOVA, $p<0.05 ; t$ test: $4 \mathrm{~h}$ vs $0.5 \mathrm{~h},{ }^{*} p<0.04 ; 4 \mathrm{~h}$ vs $1 \mathrm{~h},{ }^{*} p<0.03 ; 4 \mathrm{~h}$ vs $6 \mathrm{~h}, p=0.89 ; n=$ 10). $\boldsymbol{B}$, Protein synthesis was elevated in Fmr $1 \mathrm{KO}$ versus WT hippocampus ( $t$ test, ${ }^{*} p<0.02 ; n=13$ ). Differences in protein synthesis are exemplified by representative autoradiographs and total protein stain of the same membrane. $C$, Representative immunoblots and autoradiographs show IPs for $\alpha$-CaMKII and GAPDH from WT and Fmr 1 KO slices metabolically labeled with 50 $\mu \mathrm{Ci} / \mathrm{ml}{ }^{35} \mathrm{~S}$-Met/Cys for 1 h. D, Quantification of multiple experiments reveals that the ratio of ${ }^{35} \mathrm{~S}$-incorporated total $\alpha$-CaMKII is higher in Fmr 1 KO slices than WT slices ( $t$ test, ${ }^{*} p<0.04 ; n=6$ ). In contrast, the ratio of ${ }^{35}$ S-incorporated/total GAPDH is not elevated in $F m r 1 \mathrm{KO}$ versus WT slices ( $t$ test $p=0.31 ; n=5$ ). $\boldsymbol{E}$, During the first 5 min of metabolic labeling, WT and $F m r 1 \mathrm{KO}$ slices were exposed to $50 \mu \mathrm{M}$ MPEP or vehicle. Quantification of multiple experiments shows that MPEP treatment corrects protein synthesis in the Fmr $1 \mathrm{KO}$ back to WT levels ( $t$ test, ${ }^{*} p<0.03 ; n=8$ ). This treatment had no significant effect on WT protein synthesis $(t$ test, $p=0.58 ; n=8)$. F, WT and Fmr 1 KO slices were preincubated $\pm 10 \mu \mathrm{M}$ MPEP for 30 min, then metabolically labeled $\pm 10 \mu \mathrm{M}$ MPEP for $30 \mathrm{~min}$. Measurements taken from isolated CA1 regions show that MPEP corrects excessive protein synthesis in Fmr 1 KO CA1 back to WT levels ( $t$ test, ${ }^{*} p<0.02 ; n=8$ ). This treatment had no effect on WT CA1 ( $t$ test $p=0.24 ; n=$ 8). G, WT and Fmr $1 \mathrm{KO}$ slices were stimulated $\pm 100 \mu \mathrm{M}$ DHPG during the first 5 min of metabolic labeling. DHPG stimulation caused a robust increase in protein synthesis in WT $\left(t\right.$ test, $\left.{ }^{*} p<0.0001\right)$, but not $F m r 1 \mathrm{KO}$ ( $t$ test, $\left.p=0.62\right)$, hippocampus $(n=8)$. $N$ represents number of animals per group, where $1-2$ slices were analyzed per animal. Error bars represent SEM.

${ }^{*} p<0.002 ; n=5$ ) (supplemental Fig. S2 B, available at www. jneurosci.org as supplemental material). However, a comparison of ${ }^{35} \mathrm{~S}$-incorporated/total ratios reveals that GAPDH is not excessively translated in Fmr1 KO slices (WT $100 \pm$ 9\%, KO $88 \pm 6 \%$; $t$ test $p=0.31 ; n=5$; Fig. $1 D$ ). These findings suggest that the elevated total protein synthesis we detect in the Fmrl KO reflects derepression of FMRP-regulated translation.

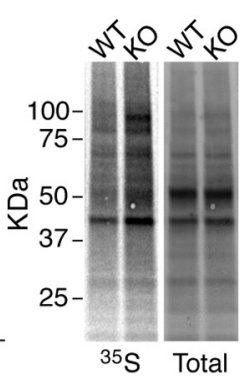

Excessive protein synthesis in the Fmr1 KO is corrected by acute, pharmacological antagonism of mGluR5

To see whether acute pharmacological inhibition of mGluR5 could effectively reduce the excess protein synthesis seen in juvenile Fmr1 KO hippocampus, we exposed slices to the mGluR5 antagonist, MPEP. Interestingly, our initial experiments revealed that a $5 \mathrm{~min}$ application of $50 \mu \mathrm{M}$ MPEP, which had no significant effect on WT protein synthesis, was sufficient to reduce the protein synthesis in Fmr1 KO slices back to WT levels (WT control $100 \pm 1 \%$, KO control $117 \pm 2 \%$, WT MPEP $104 \pm 2 \%$, KO MPEP $95 \pm 2 \%$; ANOVA genotype $\times$ treatment $p<0.05$; $n=8$; Fig. $1 E$ ). Because we are particularly interested in the protein synthesis related to mGluR-LTD, we repeated the experiment using an MPEP treatment that has been shown to block LTD (Hou and Klann, 2004) and measured changes in protein synthesis specifically in the CA1 region of dorsal hippocampus. Slices were preincubated $\pm 10 \mu \mathrm{M}$ MPEP for $30 \mathrm{~min}$, then protein synthesis was measured for another $30 \mathrm{~min} \pm 10 \mu \mathrm{M}$ MPEP. Measurements restricted to microdissected area CA1 showed that although MPEP had no effect on protein synthesis under basal conditions in WT slices, it was sufficient to correct elevated protein synthesis in Fmr1 KO slices (WT control $100 \pm 4 \%$, $\mathrm{KO}$ control $117 \pm 6 \%$, WT MPEP $107 \pm$ $7 \%$, KO MPEP $104 \pm 6 \%$; ANOVA genotype $\times$ treatment $p<0.02 ; n=8$; Fig. $1 F$ ). These data represent the first demonstration that excessive protein synthesis in the Fmr1 KO hippocampus can be rapidly corrected by acute pharmacological inhibition of mGluR5. Thus, the elevated protein synthesis in the Fmrl $\mathrm{KO}$ is downstream of constitutive mGluR5 activation.

\section{mGluR-mediated protein synthesis is} mimicked and occluded in the Fmr1 KO In hippocampal slices from Fmr1 KO mice, LTD induced by application of DHPG is greater in magnitude (Huber et al., 2002) and qualitatively unlike WT because it is not reduced by protein synthesis inhibitors (Hou et al., 2006; Nosyreva and Huber, 2006). These findings have led to the suggestion that proteins responsible for long-term expression of LTD are rapidly synthesized in response to mGluR activation in WT, and constitutively overexpressed in Fmr1 KO hippocampus. Gp1 mGluR activation has been shown to lead to increased protein synthesis in a variety of systems (Weiler and Greenough, 1993; Raymond et al., 2000; Job and Eberwine, 2001; Todd et al., 2003; Shin et al., 2004; Muddashetty et al., 2007). However, whether activation of mGluRs under LTD conditions leads to an increase 
A

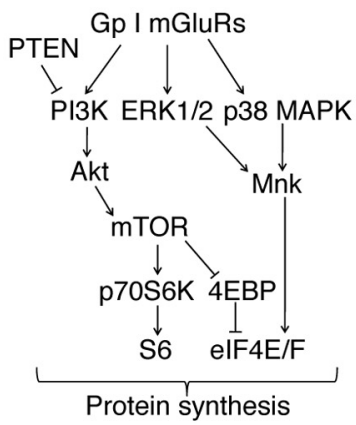

B

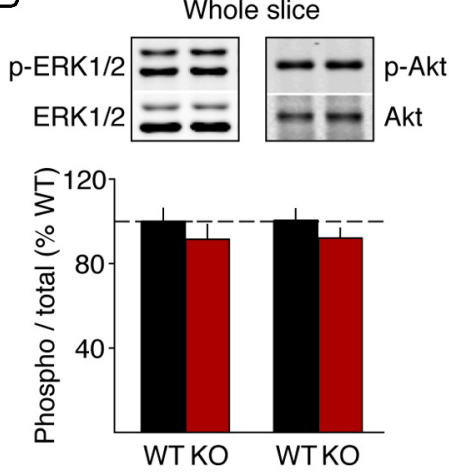

C

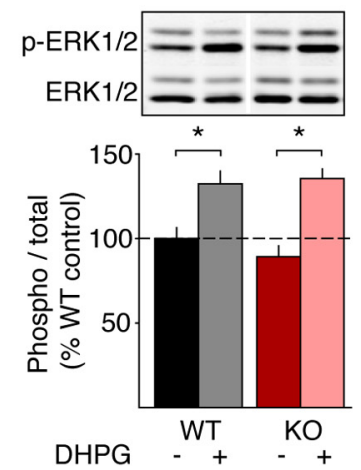

Whole slice

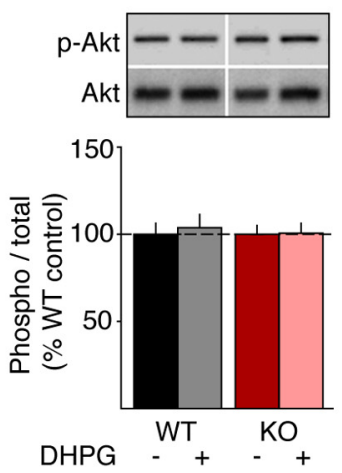

D
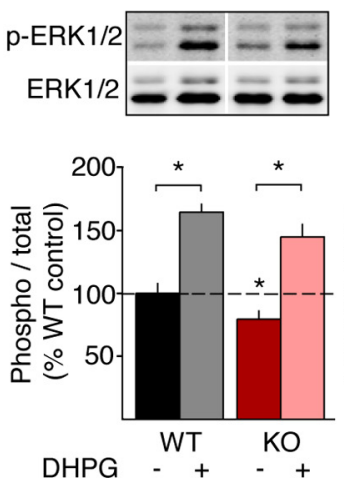

CA1 region
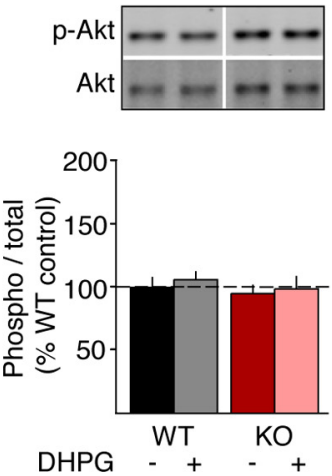

E

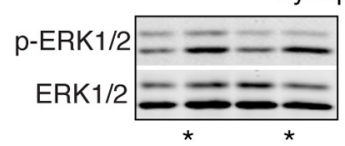

Synaptoneurosomes

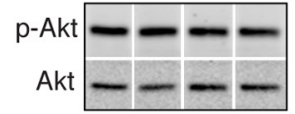

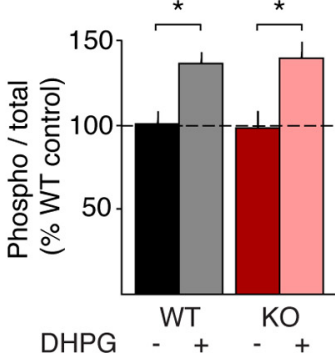

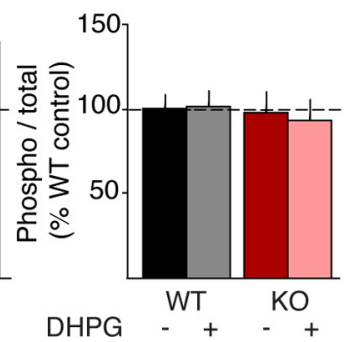

$F$
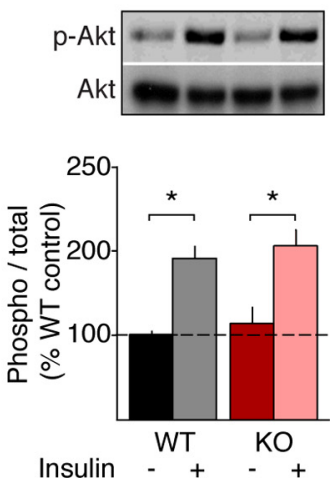

Figure 2. Basal and DHPG-evoked MAPK and PI3K signaling appears normal in the Fmr $1 \mathrm{KO}$. A, Schematic shows signaling components of the PI3K and MAPK families thought to be downstream of mGluR5 (Proud, 2007). B, Basal activation (phosphorylation) states of ERK1/2 and Akt were measured in untreated hippocampal slices from WT and Fmr $1 \mathrm{KO}$, the majority of which were used for the assay of basal protein synthesis. Results reveal no difference in either ERK1/2 ( $t$ test, $p=0.223$ ) or Akt ( $t$ test, $p=0.12$ ) activation in Fmr 1 K0 versus WT ( $n=27$ ). C, Gp1 mGluR-mediated activation of ERK1/2 was measured immediately after application of $100 \mu \mathrm{m} \mathrm{DHPG} \mathrm{for} 5$ min. Results reveal that DHPG significantly increases ERK1/2 activation in both WT $\left(t\right.$ test, $\left.{ }^{*} p<0.0001\right)$ and Fmr $1 \mathrm{KO}$ ( $t$ test, $\left.{ }^{*} p<0.0001\right)$ slices $(n=14)$. Interestingly, activation of Akt was not observed in either WT ( $t$ test, $\left.p=0.47\right)$ or $F m r 1$ KO ( $t$ test, $\left.p=0.96\right)$ slices $(n=14)$. D, ERK1/2 and Akt activation was measured in microdissected CA1 after 5 min application of $100 \mu \mathrm{M}$ DHPG. Analyses reveal that stimulation of Gp1 mGluRs leads to a significant activation of ERK1/2 in both WT ( $t$ test, ${ }^{*} p<$ $0.0001)$ and $F m r 1 \mathrm{KO}\left(t\right.$ test, $\left.{ }^{*} p<0.006\right)$ CA1 $(n=8)$. A slight but significant reduction in basal ERK1/2 activation is seen in Fmr $1 \mathrm{KO}$ CA1 ( $t$ test, $\left.{ }^{*} p<0.008\right)$. Basal activation of Akt in $F m r 1 \mathrm{KO} 0$ CA1 is not significantly different from WT CA1 ( $t$ test, $p=0.65$ ), and no activation of Akt is observed in either WT ( $t$ test, $p=0.61$ ) or Fmr 1 KO ( $t$ test, $p=0.76)$ CA1 $(n=8)$. E, Synaptoneurosomes were isolated from sets of slices treated with $100 \mu \mathrm{m}$ DHPG for $5 \mathrm{~min}$, and levels of ERK1/2 and Akt activation were assessed. Results reveal a significant activation of ERK1/2 in both WT (t test, ${ }^{*} p<0.001$ ) and Fmr $1 \mathrm{KO}$ ( $t$ test, ${ }^{*} p<0.01$ ) synaptoneurosomes ( $n=10$ sets of slices from 7 animals). No activation of Akt was observed in either WT ( $t$ test, $\left.p=0.88\right)$ or Fmr1 K0 ( $t$ test, $p=0.47$ ) synaptoneurosomes ( $n=10$ sets of slices from 7 animals). $\boldsymbol{F}$, Activation of Akt was measured after a 10 min application of $1 \mu \mathrm{m}$ insulin. Results reveal a robust activation of Akt in both WT ( $t$ test, $\left.{ }^{*} p<0.001\right)$ and $F m r 1 \mathrm{KO}\left(t\right.$ test, $\left.{ }^{*} p<0.05\right)$ slices $(n=8)$. Representative immunoblots reflect quantified results. Unless otherwise noted, $n$ represents number of animals per group, where $1-2$ slices were analyzed per animal. Error bars represent SEM.

in protein synthesis in hippocampal slice has not been directly tested.

We observed that the same treatment that induces LTD in hippocampal slices (100 $\mu \mathrm{M}$ DHPG, $5 \mathrm{~min}$ ) also significantly increases protein synthesis in WT slices (Fig. 1G). Interestingly, however, the same treatment does not stimulate protein synthesis over the elevated baseline level in Fmr1 KO hippocampal slices (WT control $100 \pm 2 \%$, WT DHPG $119 \pm 2 \%$, KO control $110 \pm$ $5 \%$, KO DHPG $112 \pm 4 \%$; ANOVA genotype $\times$ treatment $p<$ $0.02 ; n=8$; Fig. $1 G$ ). Thus, genetic deletion of FMRP appears to mimic and occlude the effect of DHPG on protein synthesis.

\section{No detectable difference in basal mGluR signaling under} conditions of elevated protein synthesis

Previous studies have shown that DHPG stimulation leads to activation of the MAPK/ERK1/2 pathway (Ferraguti et al., 1999; Gallagher et al., 2004; Hou and Klann, 2004). More recently, activation of the PI3K-Akt-mTOR pathway has been reported (Hou and Klann, 2004; Sharma et al., 2010). Both pathways are linked to the initiation of $5^{\prime}$ cap-dependent translation of mRNAs (Fig. 2 A). ERK1/2 activates the MAPK-interacting kinase (Mnk),
Table 1. No basal upregulation of MAPK or PI3K pathways in the Fmr 1 KO

\begin{tabular}{lllcl}
\hline \multirow{2}{*}{ Protein } & \multirow{2}{*}{$\begin{array}{l}\text { Phosphorylation } \\
\text { site }\end{array}$} & \multicolumn{2}{l}{ Phospho/total } & \\
\cline { 3 - 4 } & WT & K0 & Animals \\
\hline Erk1/2 & Thr202/Tyr204 & $100 \pm 6 \%$ & $92 \pm 7 \%$ & 27 \\
Akt & Ser473 & $100 \pm 6 \%$ & $92 \pm 4 \%$ & 27 \\
p38* & Thr180/Tyr182 & $100 \pm 8 \%$ & $85 \pm 7 \%$ & 10 \\
PTEN & Ser380/Thr382/383 & $100 \pm 13 \%$ & $100 \pm 11 \%$ & 10 \\
mTOR & Ser2448 & $100 \pm 7 \%$ & $111 \pm 8 \%$ & 16 \\
p70S6K & Thr389 & $100 \pm 8 \%$ & $102 \pm 6 \%$ & 19 \\
S6 & Ser235/236 & $100 \pm 12 \%$ & $79 \pm 7 \%$ & 17 \\
\hline
\end{tabular}

Basal activation (phosphorylation) states of ERK1/2, p38, and the PI3K pathway proteins PTEN, Akt, mTOR, p7056K and $\mathrm{S} 6$ were measured in untreated hippocampal slices from Fmr $1 \mathrm{KO}$ and WT, the majority of which were used for measurement of protein synthesis. Results are expressed as percent average WT \pm SEM. For all proteins, no significant increase was seen in $F m r 1 \mathrm{KO}$ as compared to WT. In contrast, a small but significant decrease in the activation state of $\mathrm{p} 38$ ( $t$ test, ${ }^{*} p<0.05$ ) was observed in Fmr $1 \mathrm{KO}$. For each animal, $1-2$ slices were analyzed. ERK1/2 and Akt data are graphically represented in Figure $2 . t$ test, ${ }^{*} p<0.05$.

which leads to phosphorylation of eukaryotic initiation factor $4 \mathrm{E}$ (eIF4E) (Proud, 2007). Akt facilitates the activation of mTOR, which derepresses eIF4E by phosphorylating eIF4E binding proteins (4EBPs) (Gingras et al., 1999). mTOR also initiates translation of $5^{\prime}$ TOP mRNA, which is linked to the activation of 
Table 2. No difference in mGluR-stimulated MAPK or PI3K activation in the Fmr1 KO

\begin{tabular}{|c|c|c|c|c|c|c|}
\hline \multirow[b]{2}{*}{ Protein } & \multirow[b]{2}{*}{ Phosphorylation site } & \multicolumn{4}{|l|}{ Phospho/total } & \multirow[b]{2}{*}{ Animals } \\
\hline & & WT & WT + DHPG & KO & $\mathrm{KO}+\mathrm{DHPG}$ & \\
\hline Erk1/2* & Thr202/Tyr204 & $100 \pm 6 \%$ & $132 \pm 8 \%$ & $90 \pm 6 \%$ & $135 \pm 6 \%$ & 13 \\
\hline Akt & Ser473 & $100 \pm 5 \%$ & $104 \pm 6 \%$ & $100 \pm 5 \%$ & $100 \pm 6 \%$ & 14 \\
\hline p38 & Thr180/Tyr182 & $100 \pm 5 \%$ & $112 \pm 9 \%$ & $84 \pm 5 \%$ & $94 \pm 7 \%$ & 9 \\
\hline PTEN & Ser380/Thr382/383 & $100 \pm 10 \%$ & $91 \pm 11 \%$ & $80 \pm 11 \%$ & $94 \pm 12 \%$ & 7 \\
\hline mTOR & Ser2448 & $100 \pm 11 \%$ & $105 \pm 8 \%$ & $117 \pm 12 \%$ & $102 \pm 5 \%$ & 12 \\
\hline p70S6K & Thr389 & $100 \pm 7 \%$ & $105 \pm 3 \%$ & $119 \pm 7 \%$ & $100 \pm 9 \%$ & 8 \\
\hline S6 & Ser235/236 & $100 \pm 10 \%$ & $97 \pm 9 \%$ & $85 \pm 10 \%$ & $83 \pm 3 \%$ & 6 \\
\hline
\end{tabular}

Hippocampal slices were stimulated with $100 \mu \mathrm{M}$ DHPG or vehicle for exactly 5 min. Activation states of ERK1/2, p38, and the PI3K pathway proteins PTEN, Akt, $m$ TOR, p70S6K, and S6 were measured in Fmr 1 K0 and WT. Results are expressed as \% average WT control \pm SEM Of the proteins examined, only ERK1/2 was activated by Gp 1 mGluR stimulation (ANOVA treatment, $p<0.0001$, genotype $x$ treatment, $p=0.07$ ). This increase was seen in both WT ( $t$ test ${ }^{*} p<0.0001$ ) and $F m r 1 \mathrm{KO}$ ( $t$ test, ${ }^{*} p<0.0001$ ). A small but significant decrease in the activation state of $\mathrm{p} 38$ was also observed in $F m r 1 \mathrm{KO}$ ( $t$ test, ${ }^{*} p<0.05$ ). For each animal, $1-2$ slices were analyzed. Data from untreated slices are incorporated in the dataset shown in Table 1; ERK1/2 and Akt data are graphically represented in Figure 2. ANOVA treatment, ${ }^{*} p<0.0001$.

ribosomal protein S6 kinases (i.e., p70S6K), and the subsequent phosphorylation of S6 (Proud, 2007). Phosphorylation of both $4 \mathrm{EBP}$ and $\mathrm{p} 70 \mathrm{~S} 6 \mathrm{~K}$ are considered to be reliable and equivalent readouts of mTOR activation (Hara et al., 1998; Avruch et al., 2001; Wang et al., 2005).

Our results showing that the excessive protein synthesis in the Fmr1 KO hippocampus is reversible with MPEP application suggest one of two things: (1) mGluR5 signaling is excessive in the Fmr1 KO hippocampus, or (2) the Fmr1 KO hippocampus is hypersensitive to normal constitutive mGluR5 signaling. In an attempt to differentiate between these two options, we measured ERK1/2, p38 MAPK, and Akt activation in the same hippocampal slices from WT and Fmrl KO that had been used to measure protein synthesis. Interestingly, we observed no basal increase in either ERK1/2 or Akt activation in Fmr1 KO slices (ERK1/2: WT $100 \pm 6 \%$, KO $92 \pm 7 \%$; $t$ test $p=0.22$; Akt: WT $100 \pm 6 \%$, KO $92 \pm 4 \%$; $t$ test $p=0.12 ; n=27$; Fig. $2 B$ ), despite detecting the robust increase in protein synthesis (Fig. $1 B$ ). There was, however, a small but significant decrease in phosphorylated p38 in the Fmr $1 \mathrm{KO}\left(t\right.$ test ${ }^{\star} p<0.05 ; n=10$; Table 1$)$. This difference may reflect a compensatory downregulation in response to elevated protein synthesis, but is unlikely to be a cause of the increased protein synthesis.

To determine whether upstream or downstream effectors of these pathways were hyperactive, we examined the phosphorylation states of PTEN, a negative regulator of the PI3K pathway (Stambolic et al., 1998), as well as of the downstream components mTOR, p70S6K, and S6. In all proteins tested, no significant increase in activation state was observed in Fmr1 KO hippocampus (Table 1).

\section{Evoked mGluR-ERK1/2 signaling appears normal in the Fmr1 KO}

Results from untreated slices suggested that basal mGluR5 signaling is not excessive in the Fmr1 KO hippocampus. However, we could not exclude the possibility that we were missing a change that can only be seen with mGluR5 activation or in a specific biochemical fraction. We therefore measured activation of these pathways after $5 \mathrm{~min}$ of stimulation with $100 \mu \mathrm{M}$ DHPG, the protocol for mGluR-LTD induction. Our results revealed that there were no significant differences in activation of ERK1/2, p38, PTEN, Akt, mTOR, p70S6K, or S6 between WT and Fmr1 KO (Table 2). Interestingly, while we observed a robust activation of ERK1/2 in both WT and Fmr1 KO slices (WT control $100 \pm$ $6 \%$, WT DHPG $132 \pm 8 \%$, KO control $90 \pm 6 \%$, KO DHPG $135 \pm 6 \%$; ANOVA treatment $p<0.0001 ; n=13$; Fig. $2 C$ ) we did not observe a significant activation of Akt in these slices (WT control $100 \pm 5 \%$, WT DHPG $104 \pm 6 \%$, KO control
$100 \pm 5 \%$, KO DHPG $100 \pm 6 \%$; ANOVA treatment $p=0.57$; $n=14$; Fig. $2 C$ ). Further investigation revealed that none of the PI3K pathway members examined (PTEN, mTOR, p70S6K and S6) were activated by DHPG in either WT or Fmr1 KO slices (Table 2).

The exaggerated mGluR-LTD phenotype in the Fmr1 KO has been described in CA1 (Huber et al., 2002), and we wanted to confirm our results in this area of the hippocampus. Consistent with results from whole slices, we found no hyperactivation of ERK1/2 or Akt in area CA1 microdissected from Fmr1 KO hippocampus, nor was there any occlusion of an mGluR-stimulated response (ERK1/2: WT control $100 \pm 3 \%$, WT DHPG $164 \pm 6 \%$, KO control $79 \pm 7 \%$, KO DHPG $145 \pm 16 \%$; ANOVA treatment $p<0.0001$, genotype $\times$ treatment $p=0.95 ; n=8$; Akt: $\mathrm{WT}$ control $100 \pm 7 \%$, WT DHPG $106 \pm 6 \%$, KO control $95 \pm 6 \%$, KO DHPG $99 \pm 9 \%$; ANOVA treatment $p=0.55$, genotype $\times$ treatment $p=0.89 ; n=8$; Fig. $2 D$ ). Interestingly, a slight but significant decrease in ERK1/2 phosphorylation was seen in Fmr1 KO CA1 suggesting the possibility of compensatory downregulation in response to elevated protein synthesis $\left(t\right.$ test ${ }^{\star} p<0.008$; $n=8$; Fig. $2 D$ ). These results support the conclusion that ERK $1 / 2$ activation is neither elevated nor saturated in Fmrl KO hippocampus. Consistent with our previous results, no significant mGluR-mediated activation of Akt was observed in either WT or Fmr1 KO CA1 (Fig. 2D).

To test whether differences in mGluR-mediated signaling could be seen specifically at the synaptic level, we measured activation of ERK1/2 and Akt in synaptoneurosome fractions isolated from slices stimulated $\pm 100 \mu \mathrm{M}$ DHPG for $5 \mathrm{~min}$. Consistent with results from whole slices, we find that mGluRmediated activation of ERK1/2 is preserved in Fmr1 KO synaptoneurosomes (WT control $100 \pm 8 \%$, WT DHPG $135 \pm$ $8 \%$, KO control $98 \pm 10 \%$, KO DHPG $139 \pm 9 \%$; ANOVA treatment $p<0.0001$, genotype $\times$ treatment $p=0.68 ; n=10$ sets of slices from 7 animals; Fig. 2 E). No activation of Akt was observed in either WT or Fmr1 KO synaptoneurosomes (WT control $100 \pm 9 \%$, WT DHPG $102 \pm 10 \%$, KO control $98 \pm$ $13 \%$, KO DHPG $93 \pm 13 \%$; ANOVA treatment $p=0.79$, genotype $\times$ treatment $p=0.60 ; n=10$ sets of slices from 7 animals; Fig. $2 E$ ).

Our data suggest that the PI3K-Akt pathway is not basally hyperactive under conditions in which we observe excessive protein synthesis. To ensure that our assay was sensitive to changes in Akt activation, we exposed slices to insulin, a potent activator of the PI3K pathway (Proud, 2007). Results from these experiments show that a 10 min application of $1 \mu \mathrm{M}$ insulin leads to a robust activation of Akt in both Fmr1 KO and WT slices (WT control $100 \pm 6 \%$, WT insulin $191 \pm 16 \%$, KO control $113 \pm$ 
$21 \%$, KO insulin $205 \pm 20 \%$; ANOVA treatment $p<0.0005$, genotype $\times$ treatment $p=0.979 ; n=8$; Fig. $2 F$ ). These results suggest that the PI3K-Akt pathway is preserved, and not saturated, in Fmr1 KO slices.

Together, the results from these experiments show that differences in basal or evoked activation of mGluR5-mediated signaling do not parallel-and are therefore unlikely to account for-the differences in basal and DHPG-evoked protein synthesis in Fmr1 KO hippocampus.

\section{Inhibition of ERK1/2, but not mTOR, corrects excessive protein synthesis in the Fmr1 KO}

Our results show that the excessive protein synthesis in the Fmr1 KO can be corrected by inhibition of mGluR5, and that activation of Gp1 mGluRs leads to robust activation of ERK1/2. We therefore hypothesized that inhibition of ERK1/2 could, like MPEP, correct the excessive protein synthesis in the Fmrl KO. This hypothesis was tested using the MEK1/2-ERK1/2 inhibitor U0126, which we found robustly decreased ERK1/2 activation in WT and Fmrl $\mathrm{KO}$ at $5 \mu \mathrm{M}$ (WT control $100 \pm 15 \%$, WT U0126 $15 \pm 3 \%$; $\mathrm{KO}$ control $86 \pm 8 \%, \mathrm{KO}$ U0126 $12 \pm 2 \%$; ANOVA treatment $p<0.0001 ; n=4$; Fig. $3 B$ ). Slices were preincubated $\pm 5 \mu \mathrm{M}$ $\mathrm{U} 0126$ for $30 \mathrm{~min}$, and protein synthesis measured $\pm 5 \mu \mathrm{M} \mathrm{U} 0126$ for an additional $30 \mathrm{~min}$. Our results reveal that U0126 corrects protein synthesis in the Fmr1 KO down to WT levels (WT control $100 \pm 6 \%$, KO control $115 \pm 4 \%$, WT U0126 $94 \pm 6 \%$; KO U012691 $\pm 6 \%$; ANOVA genotype $\times$ treatment $p<0.03 ; n=9$; Fig. $3 B$ ). These results provide the first evidence that downregulation of the ERK1/2 pathway is effective in correcting a core Fmr1 KO phenotype.

In light of a recent study proposing that the Akt/mTOR pathway contributes to the exaggerated mGluR-LTD in the Fmr1 KO (Sharma et al., 2010), we examined whether application of the mTOR antagonist rapamycin could rescue the excess protein synthesis in the Fmr1 KO. Hippocampal slices were incubated \pm $20 \mathrm{~nm}$ rapamycin for $30 \mathrm{~min}$, then metabolically labeled $\pm 20 \mathrm{~nm}$ rapamycin for $30 \mathrm{~min}$. This treatment failed to correct the excess protein synthesis seen in the Fmr1 KO (WT control $100 \pm 5 \%$, KO control $115 \pm 6 \%$, WT rapamycin $103 \pm 3 \%$, KO rapamycin $125 \pm 8 \%$; ANOVA genotype $p<0.002$, ANOVA genotype $\times$ treatment $p=0.51 ; n=13$; Fig. $3 C$ ). Rapamycin was confirmed to produce robust inhibition of mTOR by monitoring the phosphorylation of p70S6K, a direct downstream target (WT control $100 \pm 19 \%$, WT rapamycin $24 \pm 5 \%$; KO control $94 \pm 14 \%$, KO rapamycin $15 \pm 4 \%$; ANOVA treatment $p<0.0001$, ANOVA genotype $\times$ treatment $p=0.90 ; n=7$; Fig. $3 C$ ). These data suggest that the Akt-mTOR pathway does not contribute directly to the excessive protein synthesis seen in the Fmr1 KO and might influence LTD by actions other than regulation of protein synthesis.

TrkB-mediated protein synthesis is occluded in the Fmr1 KO Results from our protein synthesis and signaling pathway experiments suggest that ERK1/2 links mGluR5 to protein synthesis, and that protein synthesis in the Fmr1 KO is hypersensitive to the activation of this pathway (Fig. 3D). This model would account for both the selective reduction of protein synthesis in the Fmr1 KO with MPEP and U0126, and the selective increase in protein synthesis in the WT with DHPG stimulation (Fig. 3D). A prediction of this model is that synaptic protein synthesis in response to any activator of ERK1/2 will be saturated in the Fmr1 KO hippocampus. To test this idea, we looked at protein synthesis downstream of the BDNF receptor, TrkB, in WT and Fmr1 KO slices.
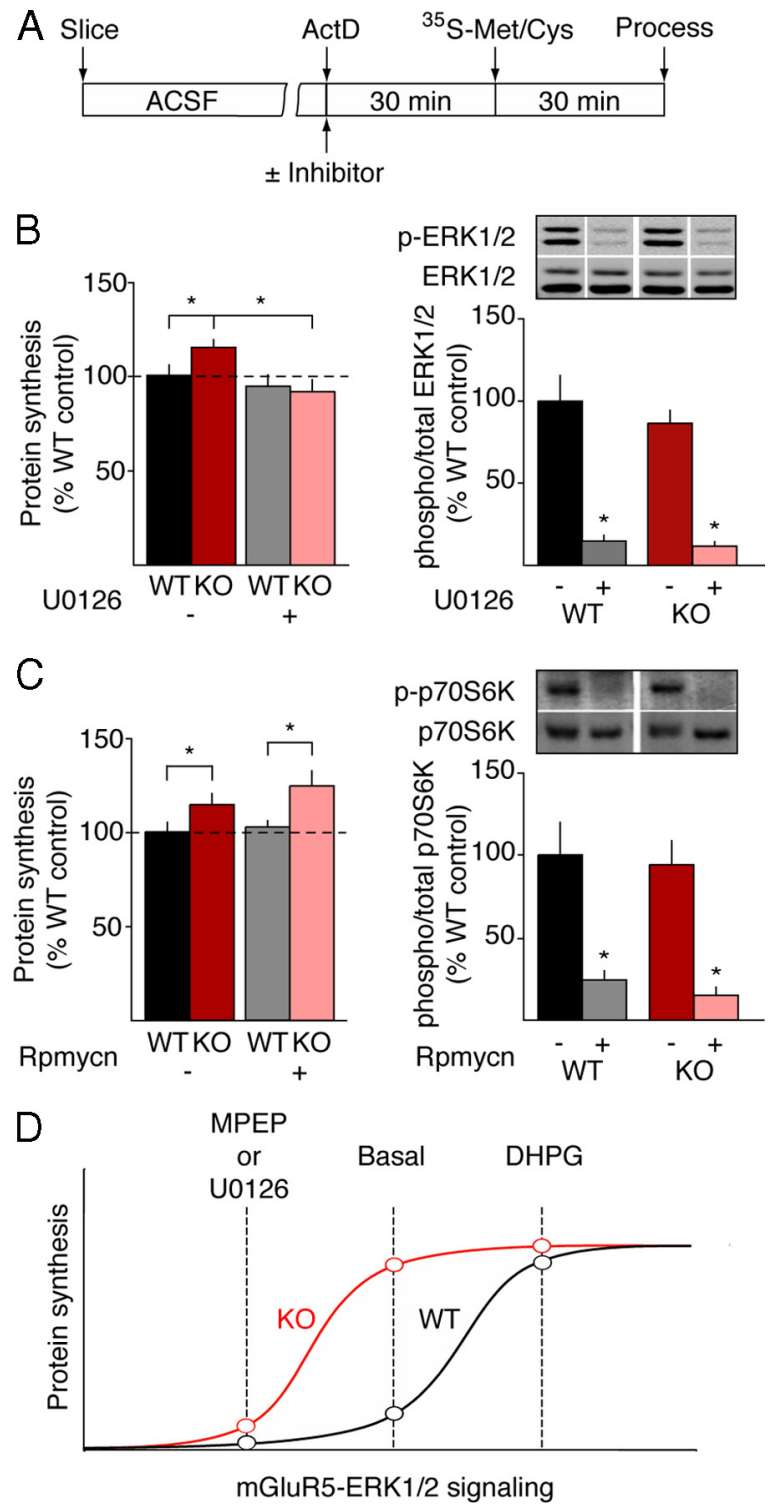

Figure 3. Inhibition of ERK1/2, but not mTOR, corrects excessive protein synthesis in the Fmr1 KO.A, Schematic illustrates experimental timeline: WT and Fmr1 KO hippocampal slices are recovered, incubated with $25 \mu \mathrm{mActD} \pm$ inhibitor for 30 min, then protein synthesismeasured \pm inhibitor for $30 \mathrm{~min}$. B, Protein synthesis and ERK1/2activation weremeasured in slices incubated $\pm 5 \mu \mathrm{mU}$ 0126. Exposuret $05 \mu \mathrm{mU} 0126$ significantly reduces protein synthesisin Fmr $1 \mathrm{KO}$ (ttest, ${ }^{*} p<0.006$ ), butnotWT (ttest $\left.p=0.15\right)$ slices ( $n=$ 9). This concentration of U0126 significantly reduced ERK1/2 activation in both WT ( $t$ test, ${ }^{*} p<0.01$ ) and Fmr1 KO ( $t$ test, ${ }^{*} p<0.005$ ) slices $(n=4)$. C, Protein synthesis and p70S6K activation were measured in slices incubated $\pm 20 \mathrm{~nm}$ rapamycin. Exposure to $20 \mathrm{~nm}$ rapamycin does not correct protein synthesis in the Fmr $1 \mathrm{KO}$ (WT control vs KO control, $t$ test, ${ }^{*} p<0.03$; WT rapamycin vs KO rapamycin, $t$ test, ${ }^{*} p<0.02 ; n=$ 13). This dose of rapamycin robustly reduces $p 7056$ Kactivation in both WT ( $t$ test, ${ }^{*} p<0.02$ ) and Fmr $1 \mathrm{KO}$ ( $t$ test, ${ }^{*} p<0.002$ ) slices $(n=7)$. Quantified changes are shown in representative immunoblots. N represents number of animals per group, where 1-2 slices were analyzed per animal. Error bars represent SEM. D, Our results suggest the illustrated model of the relationship between mGluR5-mediated ERK1/2 activation and synaptic protein synthesis in WT and Fmr $1 \mathrm{KO}$. In the Fmr $1 \mathrm{KO}$, the loss of FMRP renders the activation of protein synthesis the more sensitive to basal levels of mGluR5-ERK1/2 activity. Inhibition of basal mGluR5ERK1/2 with MPEP or U0126 leads to a significant decrease in Fmr $1 \mathrm{KO}$, but not WT protein synthesis due to this hypersensitivity. Conversely, DHPG does notelevate the level of protein synthesis in the Fmr 1 KO because mGluR5-ERK1/2-mediated protein synthesis is already saturated.

Activation of TrkB has been shown to result in ERK1/2dependent protein synthesis at the synapse, and this is thought to play a role in sustained LTP (Kang and Schuman, 1996; Schratt et al., 2004; Kanhema et al., 2006). 

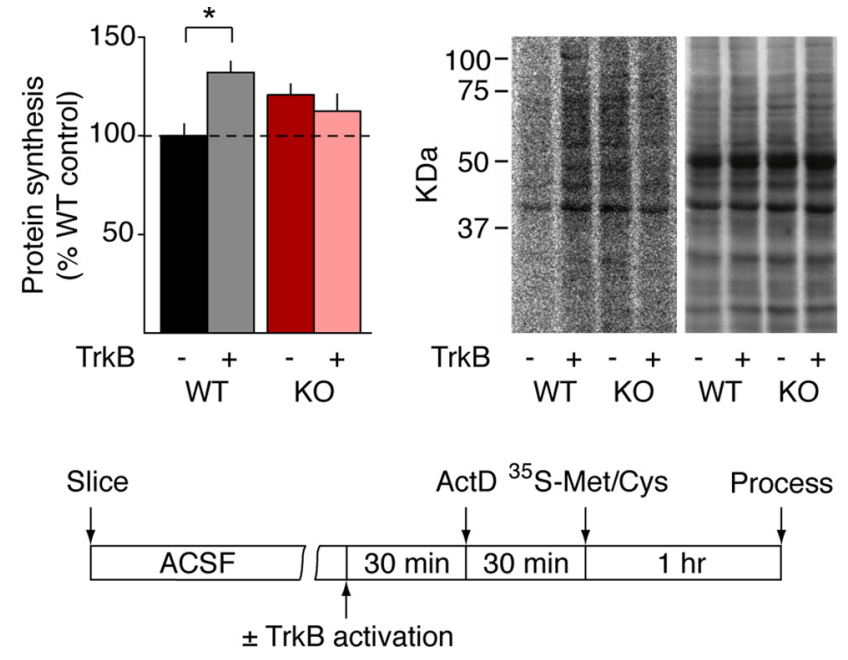

Figure 4. TrkB-mediated protein synthesis is mimicked and occluded in the Fmr1 KO. WT and $F m r 1 \mathrm{KO}$ hippocampal slices were recovered and preincubated $\pm 1 \mu \mathrm{g} / \mathrm{ml}$ anti-TrkB for 30 min, then $25 \mu \mathrm{M} \mathrm{ActD} \pm 1 \mu \mathrm{g} / \mathrm{ml}$ anti-TrkB for an additional $30 \mathrm{~min}$, and $1 \mathrm{~h}$ of protein synthesis measured $\pm 1 \mu \mathrm{g} / \mathrm{ml}$ anti-TrkB. Results show that TrkB activation leads to a significant increase in protein synthesis in WT ( $t$ test, ${ }^{*} p<0.03$ ) but not Fmr $\mathrm{KO}(t$ test, $p=0.433$ ) slices $(n=6)$. Schematic illustrates the time course of the experiment. Quantified differences are exemplified by representative autoradiograph and total protein stain of the same membrane. $N$ represents number of animals per group, where $1-2$ slices were analyzed per animal. Error bars represent SEM.

Our goal was to test TrkB-mediated translation in our hippocampal slices; however, the penetration of BDNF in brain slices has been shown to vary considerably depending on experimental conditions (Kang et al., 1996). In addition, BDNF is known to activate p75-NTR, a receptor involved in cytotoxicity (Chao, 1994). Given these limitations, we chose to employ an antibody-based TrkB activation strategy. Dimerization of Trk receptors in response to agonist binding leads to autophosphorylation and initiation of downstream signaling cascades (Jing et al., 1992). Trk antibodies lead to the same activation, and have been shown to initiate the downstream signaling and functional consequences to the same degree as agonist application for both TrkA and TrkB (Clary et al., 1994; Qian et al., 2006).

To confirm that our monoclonal antibody activated TrkB, we applied $1 \mu \mathrm{g} / \mathrm{ml}$ to mature cultured hippocampal neurons for $15 \mathrm{~min}$. Western blotting for $\mathrm{p}$-Trk Tyr490 reveals that this treatment robustly activates TrkB, and occludes further activation via $\mathrm{BDNF}$ (control $100 \pm 20 \%$, control + BDNF $553 \pm$ $53 \%$, TrkB $849 \pm 79 \%$, TrkB + BDNF $897 \pm 14 \%$; ANOVA, BDNF $p<0.002, \operatorname{TrkB} p<0.0001, \mathrm{BDNF} \times \operatorname{TrkB}, p<0.005$; $n=4$ sets of cultures) (supplemental Fig. S3, available at www.jneurosci.org as supplemental material). Importantly, this treatment also results in strong ERK1/2 activation that mimics and occludes activation via BDNF (control $100 \pm 3 \%$, control + BDNF $173 \pm 12 \%$, TrkB $252 \pm 20 \%$, TrkB + BDNF $221 \pm 22 \%$; ANOVA BDNF $p=0.187$, TrkB $p<0.002$, $\mathrm{BDNF} \times \operatorname{TrkB} p<0.02 ; n=4$ sets of cultures) (supplemental Fig. S3, available at www.jneurosci.org as supplemental material). We therefore used this approach to measure TrkBmediated translation in hippocampal slices. Slices were preincubated $\pm 1 \mu \mathrm{g} / \mathrm{ml}$ anti-TrkB for $30 \mathrm{~min}$, then ActD \pm 1 $\mu \mathrm{g} / \mathrm{ml}$ anti-TrkB for another $30 \mathrm{~min}$, and protein synthesis measured $\pm 1 \mu \mathrm{g} / \mathrm{ml}$ anti-TrkB for $1 \mathrm{~h}$ (Kelleher et al., 2004). This treatment led to a significant increase in protein synthesis
Table 3. Acute ERK1/2 inhibition eliminates AGS in the Fmr1 KO

\begin{tabular}{llllll}
\hline & Incidence & Wild running & Clonic & Tonic & Death \\
\hline K0 vehicle & $73 \%$ & $8 / 11$ & $4 / 11$ & $3 / 11$ & $2 / 11$ \\
KO SL 327 & $0 \% *$ & $0 / 11$ & $0 / 11$ & $0 / 11$ & $0 / 11$ \\
WT vehicle & $0 \% *$ & $0 / 10$ & $0 / 10$ & $0 / 10$ & $0 / 10$ \\
WT SL 327 & $0 \% *$ & $0 / 10$ & $0 / 10$ & $0 / 10$ & $0 / 10$ \\
\hline
\end{tabular}

Fmr $1 \mathrm{~K} 0$ and WT mice were injected with $100 \mathrm{mg} / \mathrm{kg} \mathrm{SL} 327$ or vehicle (50\% DMSO). After $1 \mathrm{~h}$, mice were exposed to a seizure-inducing stimulus for $2 \mathrm{~min}$, and scored for four stages of AGS: wild running (pronounced, undirected running and thrashing), clonic seizure (violent spasms accompanied by loss of balance), tonic seizure (postural rigidity in limbs), and death. Results reveal that treatment with SL 327 eliminates AGS in Fmr1 KO mice (Fisher's exact test; $\mathrm{KO}$ control versus WT control, ${ }^{*} p<0.03$; $\mathrm{KO}$ control versus $\mathrm{KOSL} 327,{ }^{*} p<0.02 ; \mathrm{KO}$ control versus WT $\left.\mathrm{SL} 327,{ }^{*} p<0.03\right)$

in WT slices, but failed to raise protein synthesis over the elevated basal level in Fmr1 KO slices (WT control $100 \pm 6 \%$, WT TrkB $132 \pm 6 \%, \mathrm{KO}$ control $121 \pm 6 \%$, KO TrkB $113 \pm$ 9\%; ANOVA genotype $\times$ treatment $p<0.02 ; n=6$; Fig. 4). These results suggest that, similar to $\mathrm{mGluR}$-mediated protein synthesis, TrkB-mediated protein synthesis is occluded (and therefore dysregulated) in the Fmr1 KO hippocampus. This finding is interesting in light of a recent study showing that BDNF-TrkB facilitated LTP is deficient in the Fmr1 KO (Lauterborn et al., 2007). It is possible that the inability of TrkB to elicit further protein synthesis in the Fmr1 KO is related to this phenotype.

\section{Inhibition of ERK1/2 eliminates audiogenic seizures in the Fmr1 KO}

If hypersensitivity to ERK1/2 pathway signaling is a core cause of pathological changes in the Fmrl KO, then treatment with an inhibitor of the ERK1/2 pathway might be expected to correct other phenotypes in the Fmr1 KO. Enhanced susceptibility to AGS is one of the most robust phenotypes observed in the Fmr1 KO mouse, and models the epilepsy seen in FXS patients (BerryKravis, 2002; Yan et al., 2005). Acute injection of MPEP has been shown to ameliorate the AGS phenotype in Fmr1 KO mice (Yan et al., 2005), and we wanted to test whether acute injection a brain-penetrant MEK1/2-ERK1/2 inhibitor (SL 327), could do the same. Fmr1 KO and WT mice were injected intraperitoneally with $100 \mathrm{mg} / \mathrm{kg}$ SL 327 (based on Zhong et al., 2009) or 50\% DMSO vehicle, and returned to their home cage for $1 \mathrm{~h}$. To initiate AGS, mice were transferred to a plastic test cage and exposed to a seizure-inducing alarm for $2 \mathrm{~min}$. During stimulus presentation, mice were scored for four stages of AGS: wild running, clonic seizure, tonic seizure, and death (Yan et al., 2005; Dölen et al., 2007; Zhong et al., 2009). All animals were injected and scored blind to genotype.

Consistent with previous studies, we observed that vehicletreated Fmr1 KO mice exhibited a 73\% incidence of AGS, in stark contrast to the $0 \%$ incidence observed in vehicle-treated WT mice (Fisher's exact test ${ }^{\star} p<0.03$; Table 3) (Yan et al., 2005; Dölen et al., 2007). Strikingly, SL 327 treatment completely eliminated AGS in the Fmr $1 \mathrm{KO}$, dropping the incidence to 0\% (Fisher's exact test ${ }^{\star} p<0.03$; Table 3 ). These results provide the first evidence that inhibition of ERK1/2 can correct in vivo phenotypes observed in the Fmr1 KO.

We also tested the hypothesis that rapamycin can inhibit AGS, based on recent evidence that mTOR signaling is altered in some biochemical preparations of Fmr1 KO brain (Sharma et al., 2010). Fmr1 KO and WT mice were injected intraperitoneally with $6 \mathrm{mg} / \mathrm{kg}$ rapamycin (based on Ehninger et al., 2008; Meikle et al., 2008) or 100\% DMSO vehicle, and tested for AGS after $1 \mathrm{~h}$. Unlike the ERK inhibitor, rapamycin failed to significantly re- 
Table 4. Acute mTOR inhibition does not eliminate AGS in the Fmr1 KO

\begin{tabular}{lccccc}
\hline & Incidence & Wild running & Clonic & Tonic & Death \\
\hline KO vehicle & $63 \%$ & $10 / 16$ & $9 / 16$ & $5 / 16$ & $1 / 16$ \\
KO rapamycin & $33 \%$ & $6 / 18$ & $1 / 18$ & $1 / 18$ & $0 / 18$ \\
WT vehicle & $0 \%^{*}$ & $0 / 16$ & $0 / 16$ & $0 / 16$ & $0 / 16$ \\
WT rapamycin & $0 \% *$ & $0 / 15$ & $0 / 15$ & $0 / 15$ & $0 / 15$ \\
\hline
\end{tabular}

Fmr $1 \mathrm{KO}$ and WT mice were injected with $6 \mathrm{mg} / \mathrm{kg}$ rapamycin or vehicle (100\% DMSO). After $1 \mathrm{~h}$, mice were exposed to a seizure-inducing stimulus for $2 \mathrm{~min}$, and scored for wild running, clonic seizure, tonic seizure, and death. Results reveal that treatment with rapamycin does not significantly reduce the incidence of AGS in Fmr1 KO mice (Fisher's exact test; $\mathrm{KO}$ control versus $\mathrm{WT}$ control, ${ }^{*} p<0.005 ; \mathrm{K} 0$ control versus $\mathrm{KO}$ rapamycin, $p=0.372 ; \mathrm{KO}$ control versus WT rapamycin $\left.{ }^{*} p<0.005\right)$. A slight decrease in AGS incidence was observed in this cohort of vehicle-treated Fmr 7 $\mathrm{KO}$ mice (cf. Table 3), which we ascribe to the higher concentration of DMSO required to solubilize rapamycin and ensure proper absorption.

duce the incidence of AGS in the Fmr1 KO (Fisher's exact test KO vehicle vs WT vehicle ${ }^{\star} p<0.005, \mathrm{KO}$ vehicle vs $\mathrm{KO}$ rapamycin $p=0.372$; Table 4). Together, these results suggest that acute inhibition of ERK1/2, but not mTOR, can correct the AGS phenotype in the Fmr1 KO.

\section{Discussion}

Although reduction of mGluR5 activity has been shown to correct multiple phenotypes in the Fmr1 KO mouse (Aschrafi et al., 2005; Yan et al., 2005; Tucker et al., 2006; Dölen et al., 2007; Nakamoto et al., 2007; de Vrij et al., 2008; Qiu et al., 2009), the molecular basis has been unclear. We show here, for the first time, that acute pharmacological inhibition of either mGluR5 or the ERK1/2 signaling pathway is sufficient to normalize protein synthesis in Fmr1 KO hippocampus to WT levels. The elevated protein synthesis observed in the Fmr1 KO mimics and occludes any further increases with DHPG stimulation. However, neither basal nor stimulated activation of either the MAPK or PI3K signaling pathways were found to be increased in the Fmr1 KO. Thus, the cause of increased protein synthesis in the Fmr1 KO brain appears to be increased sensitivity of the protein synthetic machinery to mGluR5-ERK1/2 signaling, rather than increased mGluR5-ERK1/2 signaling per se (Fig. 5). Consistent with this model, we find that protein synthesis stimulated via another synaptic activator of ERK1/2, the TrkB receptor, is also saturated in Fmr1 KO hippocampus. Hypersensitivity to ERK1/2 pathway activation appears to be relevant to the disorder in vivo as we found that pharmacological antagonism of this pathway completely eliminates the AGS phenotype in the Fmr1 KO.

A well documented mechanism of translational control is the modulation of mRNA availability to the ribosome (Richter, 2007). Given that FMRP has been estimated to bind $4 \%$ of all brain mRNAs (Ashley et al., 1993), it is possible that derepression and "leaky" translation of these mRNAs in response to basal ERK1/2 signaling causes the elevated protein synthesis seen in the Fmr1 KO. Consistent with this idea, the mRNA granule population, thought to represent translationally dormant mRNAs, is reduced in the brains of Fmr1 KO versus WT mice (Aschrafi et al., 2005). Furthermore, acute in vivo administration of MPEP in the Fmr1 $\mathrm{KO}$ animals was sufficient to shift the mRNA granule population closer to the WT value. Considered together with the current findings, the data suggest that mGluR5 is a major initiator of activity-regulated synaptic protein synthesis in the brain, and that constitutive mGluR5-ERK1/2 signaling is responsible for much of the excessive protein synthesis in the Fmr1 KO under basal conditions.

Basal protein synthesis in the WT hippocampal slice preparation was not significantly reduced by either U0126 or rapamycin (Fig. 3), but was eliminated by cycloheximide (supplemental Fig.

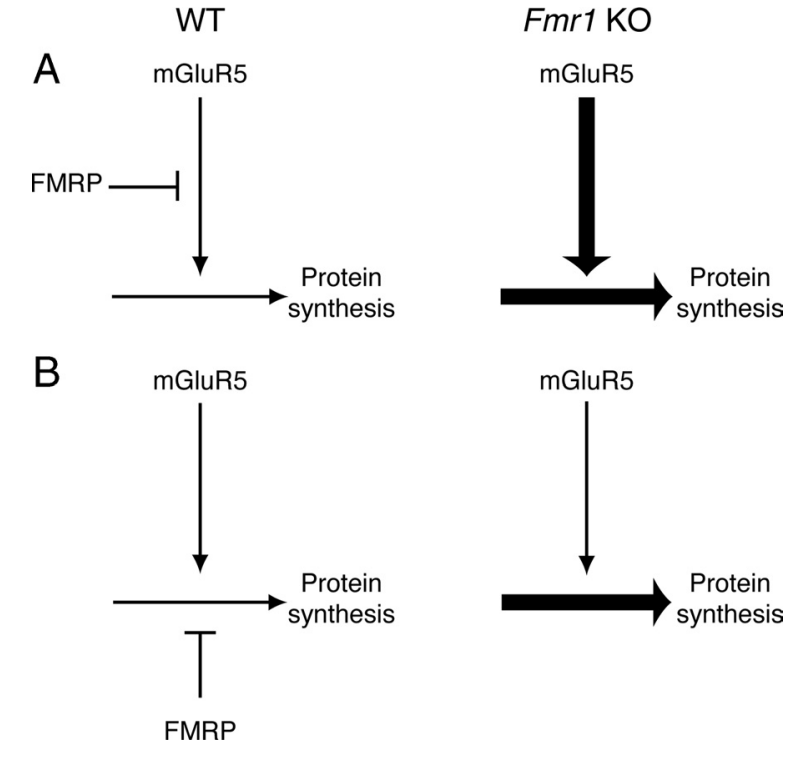

Figure 5. Heuristic models of the interaction between mGluR5 and FMRP. Illustrated are simple logical relationships between FMRP and mGluR5-stimulated synaptic protein synthesis. $\boldsymbol{A}$, a model in which FMRP or an FMRP-regulated protein specifically inhibits the signaling pathway that couples mGluR5 to translation. $\boldsymbol{B}$, An alternative model in which signaling is unaffected in the absence of FMRP, but the consequences on protein synthesis are exaggerated. The results of the current investigation favor model $B$.

S1, available at www.jneurosci.org as supplemental material). Although it is possible that increased exposure to the inhibitors might reveal some inhibition of protein synthesis (e.g., Kelleher et al., 2004; Nie et al., 2010), the treatments we used were sufficient to produce substantial inhibition of MEK and mTOR enzymatic activity as assayed by reduced levels of phosphorylated ERK and p70S6K, respectively. Thus, the data suggest that under the conditions of our experiments, basal ERK and mTOR signaling contribute little to basal protein synthesis in the WT. The residual protein synthesis in the presence of inhibitors is either constitutive or driven by other signaling pathways.

Activation of mGluRs has been shown to stimulate the ERK1/2 pathway in a wide variety of systems, including cell lines (Ferraguti et al., 1999), cultured neurons (Mao et al., 2005), striatum (Choe and Wang, 2001), spinal cord (Adwanikar et al., 2004), hippocampal slice (Berkeley and Levey, 2003; Gallagher et al., 2004), and retinal pigment epithelial cells (García et al., 2008). Although recent studies have shown an activation of Akt (Hou and Klann, 2004; Sharma et al., 2010) and mTOR (Antion et al., 2008; Ronesi and Huber, 2008; Sharma et al., 2010) in response to Gp1 mGluR activation, we did not observe this under the conditions of our experiment. It is possible that this pathway is activated by DHPG at earlier or later time points following stimulation than what we examined. However, the data do indicate that this pathway is not hyperactive under basal conditions in Fmr1 KO slices that exhibit excessive protein synthesis. Failure to observe increased activation of either ERK1/2 or Akt pathways under basal conditions is not accounted for by an insensitivity of our assay to detect increases, as evidenced by the effects of DHPG on ERK and insulin on Akt (Fig. 2).

Our findings contrast with a recent study by Sharma et al. (2010) who showed increased Akt-mTOR pathway activation in the Fmr1 KO hippocampus, attributed by the authors to be caused by elevated expression of the PI3K enhancer protein PIKE (Sharma et al., 2010). One key difference between our study and 
theirs is the preparation of the Fmr1 KO tissue. Our preparation was optimized to measure differences in protein metabolism in a physiologically stable tissue slice whereas theirs was optimized to capture early postmortem differences in protein phosphorylation. To ensure that we could replicate their findings, we probed the status of Akt and mTOR phosphorylation in homogenates from rapidly dissected hippocampus and similarly observed an increase in p-Akt and p-mTOR in the Fmr1 KO relative to WT (supplemental Fig. S4, available at www.jneurosci.org as supplemental material). This difference observed in freshly dissected tissue could reflect the status in vivo or, equally likely, a differential response to postmortem stress such as anoxia or rapid cooling. Regardless, our results strongly suggest that elevated AktmTOR signaling is not a cause of elevated protein synthesis in the Fmr1 KO (Fig. 5). First, we do not see evidence for increased Akt-mTOR signaling under experimental conditions that reveal an elevation in hippocampal protein synthesis quantitatively identical to the status in vivo (Qin et al., 2005). Second, the mTOR inhibitor rapamycin does not affect the basal increase in protein synthesis in the Fmr1 KO slices. As Sharma et al. suggest, increased activation of the Akt-mTOR pathway could be a consequence of overexpression of the regulatory protein PIKE. In this case, it seems more appropriate to view differences in the mTOR pathway as a consequence rather than a cause of increased mGluR5-regulated protein synthesis in the Fmr1 KO. That aberrant $m$ TOR pathway activation may be distal to increased protein synthesis in fragile $\mathrm{X}$ in no way diminishes the possible therapeutic significance of that discovery. However, our finding that rapamycin treatment fails to prevent AGS (Table 4) suggests that elevated mTOR activity may not be centrally involved in epileptogenesis associated with FXS.

Our results showing that protein synthesis downstream of TrkB activation is saturated in the Fmrl KO, and that inhibition of ERK1/2 signaling can correct excessive protein synthesis, suggest that a core defect in FXS is leaky translation in response to ERK1/2 activity. Supporting this, we show that acute pharmacological antagonism of ERK1/2 completely rescues the AGS phenotype in the Fmr1 mouse (Table 3). Although the major regulator of the relevant protein synthesis activity at excitatory synapses is mGluR5, it seems likely that other neurotransmitter systems that signal via ERK1/2 can contribute to the pathophysiology of FXS. This insight suggests the possibility of additional therapeutic targets in addition to mGluR5 for the treatment of the core pathophysiology of this disorder in humans.

\section{References}

Adwanikar H, Karim F, Gereau RW 4th (2004) Inflammation persistently enhances nocifensive behaviors mediated by spinal group I mGluRs through sustained ERK activation. Pain 111:125-135.

Antion MD, Hou L, Wong H, Hoeffer CA, Klann E (2008) mGluRdependent long-term depression is associated with increased phosphorylation of $\mathrm{S} 6$ and synthesis of elongation factor $1 \mathrm{~A}$ but remains expressed in S6K-deficient mice. Mol Cell Biol 28:2996-3007.

Aschrafi A, Cunningham BA, Edelman GM, Vanderklish PW (2005) The fragile $\mathrm{X}$ mental retardation protein and group I metabotropic glutamate receptors regulate levels of mRNA granules in brain. Proc Natl Acad Sci U S A 102:2180-2185.

Ashley CT Jr, Wilkinson KD, Reines D, Warren ST (1993) FMR1 protein: conserved RNP family domains and selective RNA binding. Science 262:563-566.

Auerbach BD, Bear MF (2010) Loss of the fragile X mental retardation protein decouples metabotropic glutamate receptor dependent priming of long-term potentiation from protein synthesis. J Neurophysiol 104:10471051.

Avruch J, Belham C, Weng Q, Hara K, Yonezawa K (2001) The p70 S6 kinase integrates nutrient and growth signals to control translational capacity. Prog Mol Subcell Biol 26:115-154.

Banko JL, Hou L, Poulin F, Sonenberg N, Klann E (2006) Regulation of eukaryotic initiation factor $4 \mathrm{E}$ by converging signaling pathways during metabotropic glutamate receptor-dependent long-term depression. J Neurosci 26:2167-2173.

Bear MF, Huber KM, Warren ST (2004) The mGluR theory of fragile X mental retardation. Trends Neurosci 27:370-377.

Berkeley JL, Levey AI (2003) Cell-specific extracellular signal-regulated kinase activation by multiple $G$ protein-coupled receptor families in hippocampus. Mol Pharmacol 63:128-135.

Berry-Kravis E (2002) Epilepsy in fragile X syndrome. Dev Med Child Neurol 44:724-728.

Bolduc FV, Bell K, Cox H, Broadie KS, Tully T (2008) Excess protein synthesis in Drosophila fragile X mutants impairs long-term memory. Nat Neurosci 11:1143-1145.

Brown V, Jin P, Ceman S, Darnell JC, O’Donnell WT, Tenenbaum SA, Jin X, Feng Y, Wilkinson KD, Keene JD, Darnell RB, Warren ST (2001) Microarray identification of FMRP-associated brain mRNAs and altered mRNA translational profiles in fragile X syndrome. Cell 107:477-487.

Chao MV (1994) The p75 neurotrophin receptor. J Neurobiol 25:13731385.

Chen WS, Bear MF (2007) Activity-dependent regulation of NR2B translation contributes to metaplasticity in mouse visual cortex. Neuropharmacology 52:200-214.

Choe ES, Wang JQ (2001) Group I metabotropic glutamate receptors control phosphorylation of CREB, Elk-1 and ERK via a CaMKII-dependent pathway in rat striatum. Neurosci Lett 313:129-132.

Clary DO, Weskamp G, Austin LR, Reichardt LF (1994) TrkA cross-linking mimics neuronal responses to nerve growth factor. Mol Biol Cell 5:549-563.

de Vrij FM, Levenga J, van der Linde HC, Koekkoek SK, De Zeeuw CI, Nelson DL, Oostra BA, Willemsen R (2008) Rescue of behavioral phenotype and neuronal protrusion morphology in Fmrl KO mice. Neurobiol Dis 31:127-132.

Dölen G, Bear MF (2008) Role for metabotropic glutamate receptor 5 (mGluR5) in the pathogenesis of fragile $\mathrm{X}$ syndrome. J Physiol 586:1503-1508

Dölen G, Osterweil E, Rao BS, Smith GB, Auerbach BD, Chattarji S, Bear MF (2007) Correction of fragile X syndrome in mice. Neuron 56:955-962.

Ehninger D, Han S, Shilyansky C, Zhou Y, Li W, Kwiatkowski DJ, Ramesh V, Silva AJ (2008) Reversal of learning deficits in a Tsc2 $2^{+/-}$mouse model of tuberous sclerosis. Nat Med 14:843-848.

Ferraguti F, Baldani-Guerra B, Corsi M, Nakanishi S, Corti C (1999) Activation of the extracellular signal-regulated kinase 2 by metabotropic glutamate receptors. Eur J Neurosci 11:2073-2082.

Ferrari F, Mercaldo V, Piccoli G, Sala C, Cannata S, Achsel T, Bagni C (2007) The fragile $\mathrm{X}$ mental retardation protein-RNP granules show an mGluRdependent localization in the post-synaptic spines. Mol Cell Neurosci 34:343-354.

Gallagher SM, Daly CA, Bear MF, Huber KM (2004) Extracellular signalregulated protein kinase activation is required for metabotropic glutamate receptor-dependent long-term depression in hippocampal area CA1. J Neurosci 24:4859-4864.

García S, López E, López-Colomé AM (2008) Glutamate accelerates RPE cell proliferation through ERK1/2 activation via distinct receptor-specific mechanisms. J Cell Biochem 104:377-390.

Gingras AC, Raught B, Sonenberg N (1999) eIF4 initiation factors: effectors of mRNA recruitment to ribosomes and regulators of translation. Annu Rev Biochem 68:913-963.

Hara K, Yonezawa K, Weng QP, Kozlowski MT, Belham C, Avruch J (1998) Amino acid sufficiency and mTOR regulate p70 S6 kinase and eIF-4E BP1 through a common effector mechanism. J Biol Chem 273:14484-14494.

Ho OH, Delgado JY, O’Dell TJ (2004) Phosphorylation of proteins involved in activity-dependent forms of synaptic plasticity is altered in hippocampal slices maintained in vitro. J Neurochem 91:1344-1357.

Hou L, Klann E (2004) Activation of the phosphoinositide 3-kinase-Aktmammalian target of rapamycin signaling pathway is required for metabotropic glutamate receptor-dependent long-term depression. J Neurosci 24:6352-6361.

Hou L, Antion MD, Hu D, Spencer CM, Paylor R, Klann E (2006) Dynamic translational and proteasomal regulation of fragile $\mathrm{X}$ mental retardation 
protein controls mGluR-dependent long-term depression. Neuron 51:441-454.

Huber KM, Kayser MS, Bear MF (2000) Role for rapid dendritic protein synthesis in hippocampal mGluR-dependent long-term depression. Science 288:1254-1257.

Huber KM, Roder JC, Bear MF (2001) Chemical induction of mGluR5- and protein synthesis-dependent long-term depression in hippocampal area CA1. J Neurophysiol 86:321-325.

Huber KM, Gallagher SM, Warren ST, Bear MF (2002) Altered synaptic plasticity in a mouse model of fragile X mental retardation. Proc Natl Acad Sci U S A 99:7746-7750.

Jing S, Tapley P, Barbacid M (1992) Nerve growth factor mediates signal transduction through trk homodimer receptors. Neuron 9:1067-1079.

Job C, Eberwine J (2001) Identification of sites for exponential translation in living dendrites. Proc Natl Acad Sci U S A 98:13037-13042.

Kang H, Jia LZ, Suh KY, Tang L, Schuman EM (1996) Determinants of BDNF-induced hippocampal synaptic plasticity: role of the Trk B receptor and the kinetics of neurotrophin delivery. Learn Mem 3:188-196.

Kanhema T, Dagestad G, Panja D, Tiron A, Messaoudi E, Håvik B, Ying SW, Nairn AC, Sonenberg N, Bramham CR (2006) Dual regulation of translation initiation and peptide chain elongation during BDNF-induced LTP in vivo: evidence for compartment-specific translation control. J Neurochem 99:1328-1337.

Karachot L, Shirai Y, Vigot R, Yamamori T, Ito M (2001) Induction of longterm depression in cerebellar Purkinje cells requires a rapidly turned over protein. J Neurophysiol 86:280-289.

Kelleher RJ 3rd, Govindarajan A, Jung HY, Kang H, Tonegawa S (2004) Translational control by MAPK signaling in long-term synaptic plasticity and memory. Cell 116:467-479.

Kim SH, Markham JA, Weiler IJ, Greenough WT (2008) Aberrant earlyphase ERK inactivation impedes neuronal function in fragile $\mathrm{X}$ syndrome. Proc Natl Acad Sci U S A 105:4429-4434.

Kirov SA, Sorra KE, Harris KM (1999) Slices have more synapses than perfusion-fixed hippocampus from both young and mature rats. J Neurosci 19:2876-2886.

Krueger DD, Nairn AC (2007) Expression of PKC substrate proteins, GAP-43 and neurogranin, is downregulated by cAMP signaling and alterations in synaptic activity. Eur J Neurosci 26:3043-3053.

Kundel M, Jones KJ, Shin CY, Wells DG (2009) Cytoplasmic polyadenylation element-binding protein regulates neurotrophin-3-dependent beta-catenin mRNA translation in developing hippocampal neurons. J Neurosci 29:13630-13639.

Laggerbauer B, Ostareck D, Keidel EM, Ostareck-Lederer A, Fischer U (2001) Evidence that fragile $\mathrm{X}$ mental retardation protein is a negative regulator of translation. Hum Mol Genet 10:329-338.

Lauterborn JC, Rex CS, Kramár E, Chen LY, Pandyarajan V, Lynch G, Gall CM (2007) Brain-derived neurotrophic factor rescues synaptic plasticity in a mouse model of fragile X syndrome. J Neurosci 27:10685-10694.

Li Z, Zhang Y, Ku L, Wilkinson KD, Warren ST, Feng Y (2001) The fragile X mental retardation protein inhibits translation via interacting with mRNA. Nucleic Acids Res 29:2276-2283.

Lipton P, Raley-Susman KM (1999) Autoradiographic measurements of protein synthesis in hippocampal slices from rats and guinea pigs. Methods 18:127-143.

Mao L, Yang L, Tang Q, Samdani S, Zhang G, Wang JQ (2005) The scaffold protein Homer $1 \mathrm{~b} / \mathrm{c}$ links metabotropic glutamate receptor 5 to extracellular signal-regulated protein kinase cascades in neurons. J Neurosci 25:2741-2752.

Mazroui R, Huot ME, Tremblay S, Filion C, Labelle Y, Khandjian EW (2002) Trapping of messenger RNA by Fragile X Mental Retardation protein into cytoplasmic granules induces translation repression. Hum Mol Genet 11:3007-3017.

Meikle L, Pollizzi K, Egnor A, Kramvis I, Lane H, Sahin M, Kwiatkowski DJ (2008) Response of a neuronal model of tuberous sclerosis to mammalian target of rapamycin (mTOR) inhibitors: effects on mTORC1 and Akt signaling lead to improved survival and function. J Neurosci 28:5422-5432.

Merlin LR, Bergold PJ, Wong RK (1998) Requirement of protein synthesis for group I mGluR-mediated induction of epileptiform discharges. J Neurophysiol 80:989-993.

Muddashetty RS, Kelić S, Gross C, Xu M, Bassell GJ (2007) Dysregulated metabotropic glutamate receptor-dependent translation of AMPA recep- tor and postsynaptic density-95 mRNAs at synapses in a mouse model of fragile X syndrome. J Neurosci 27:5338-5348.

Nakamoto M, Nalavadi V, Epstein MP, Narayanan U, Bassell GJ, Warren ST (2007) Fragile X mental retardation protein deficiency leads to excessive mGluR5-dependent internalization of AMPA receptors. Proc Natl Acad Sci U S A 104:15537-15542.

Nie D, Di Nardo A, Han JM, Baharanyi H, Kramvis I, Huynh T, Dabora S, Codeluppi S, Pandolfi PP, Pasquale EB, Sahin M (2010) Tsc2-Rheb signaling regulates EphA-mediated axon guidance. Nat Neurosci 13:163172.

Nosyreva ED, Huber KM (2006) Metabotropic receptor-dependent longterm depression persists in the absence of protein synthesis in the mouse model of fragile X syndrome. J Neurophysiol 95:3291-3295.

Osterweil E, Wells DG, Mooseker MS (2005) A role for myosin VI in postsynaptic structure and glutamate receptor endocytosis. J Cell Biol 168:329-338.

Park S, Park JM, Kim S, Kim JA, Shepherd JD, Smith-Hicks CL, Chowdhury S, Kaufmann W, Kuhl D, Ryazanov AG, Huganir RL, Linden DJ, Worley PF (2008) Elongation factor 2 and fragile X mental retardation protein control the dynamic translation of Arc/Arg3.1 essential for mGluR-LTD. Neuron 59:70-83.

Proud CG (2007) Signalling to translation: how signal transduction pathways control the protein synthetic machinery. Biochem J 403:217-234.

Qian MD, Zhang J, Tan XY, Wood A, Gill D, Cho S (2006) Novel agonist monoclonal antibodies activate TrkB receptors and demonstrate potent neurotrophic activities. J Neurosci 26:9394-9403.

Qin M, Kang J, Burlin TV, Jiang C, Smith CB (2005) Postadolescent changes in regional cerebral protein synthesis: an in vivo study in the FMR1 null mouse. J Neurosci 25:5087-5095.

Qiu LF, Lu TJ, Hu XL, Yi YH, Liao WP, Xiong ZQ (2009) Limbic epileptogenesis in a mouse model of fragile $\mathrm{X}$ syndrome. Cereb Cortex 19:1504-1514.

Raymond CR, Thompson VL, Tate WP, Abraham WC (2000) Metabotropic glutamate receptors trigger homosynaptic protein synthesis to prolong long-term potentiation. J Neurosci 20:969-976.

Richter JD (2007) CPEB: a life in translation. Trends Biochem Sci 32:279-285.

Ronesi JA, Huber KM (2008) Homer interactions are necessary for metabotropic glutamate receptor-induced long-term depression and translational activation. J Neurosci 28:543-547.

Sajikumar S, Navakkode S, Frey JU (2005) Protein synthesis-dependent long-term functional plasticity: methods and techniques. Curr Opin Neurobiol 15:607-613.

Schratt GM, Nigh EA, Chen WG, Hu L, Greenberg ME (2004) BDNF regulates the translation of a select group of mRNAs by a mammalian target of rapamycin-phosphatidylinositol 3-kinase-dependent pathway during neuronal development. J Neurosci 24:7366-7377.

Sharma A, Hoeffer CA, Takayasu Y, Miyawaki T, McBride SM, Klann E, Zukin RS (2010) Dysregulation of mTOR signaling in fragile X syndrome. J Neurosci 30:694-702.

Shin CY, Kundel M, Wells DG (2004) Rapid, activity-induced increase in tissue plasminogen activator is mediated by metabotropic glutamate receptor-dependent mRNA translation. J Neurosci 24:9425-9433.

Stambolic V, Suzuki A, de la Pompa JL, Brothers GM, Mirtsos C, Sasaki T, Ruland J, Penninger JM, Siderovski DP, Mak TW (1998) Negative regulation of PKB/Akt-dependent cell survival by the tumor suppressor PTEN. Cell 95:29-39.

Todd PK, Mack KJ, Malter JS (2003) The fragile X mental retardation protein is required for type-I metabotropic glutamate receptor-dependent translation of PSD-95. Proc Natl Acad Sci U S A 100:14374-14378.

Tucker B, Richards RI, Lardelli M (2006) Contribution of mGluR and Fmr1 functional pathways to neurite morphogenesis, craniofacial development and fragile X syndrome. Hum Mol Genet 15:3446-3458.

Vanderklish PW, Edelman GM (2005) Differential translation and fragile X syndrome. Genes Brain Behav 4:360-384.

Verkerk AJ, Pieretti M, Sutcliffe JS, Fu YH, Kuhl DP, Pizzuti A, Reiner O, Richards S, Victoria MF, Zhang FP (1991) Identification of a gene (FMR-1) containing a CGG repeat coincident with a breakpoint cluster region exhibiting length variation in fragile X syndrome. Cell 65:905-914.

Wang X, Beugnet A, Murakami M, Yamanaka S, Proud CG (2005) Distinct signaling events downstream of mTOR cooperate to mediate the effects of 
amino acids and insulin on initiation factor 4E-binding proteins. Mol Cell Biol 25:2558-2572.

Weiler IJ, Greenough WT (1993) Metabotropic glutamate receptors trigger postsynaptic protein synthesis. Proc Natl Acad Sci U S A 90:7168-7171.

Weiler IJ, Irwin SA, Klintsova AY, Spencer CM, Brazelton AD, Miyashiro K, Comery TA, Patel B, Eberwine J, Greenough WT (1997) Fragile X mental retardation protein is translated near synapses in response to neurotransmitter activation. Proc Natl Acad Sci U S A 94:5395-5400.

Weiler IJ, Spangler CC, Klintsova AY, Grossman AW, Kim SH, BertainaAnglade V, Khaliq H, de Vries FE, Lambers FA, Hatia F, Base CK, Greenough WT (2004) Fragile X mental retardation protein is necessary for neurotransmitter-activated protein translation at synapses. Proc Natl Acad Sci U S A 101:17504-17509.
Whittingham TS, Lust WD, Christakis DA, Passonneau JV (1984) Metabolic stability of hippocampal slice preparations during prolonged incubation. J Neurochem 43:689-696.

Yan QJ, Rammal M, Tranfaglia M, Bauchwitz RP (2005) Suppression of two major Fragile X Syndrome mouse model phenotypes by the mGluR5 antagonist MPEP. Neuropharmacology 49:1053-1066.

Zalfa F, Giorgi M, Primerano B, Moro A, Di Penta A, Reis S, Oostra B, Bagni C (2003) The fragile X syndrome protein FMRP associates with BC1 RNA and regulates the translation of specific mRNAs at synapses. Cell 112:317-327.

Zhong J, Chuang SC, Bianchi R, Zhao W, Lee H, Fenton AA, Wong RK, Tiedge H (2009) BC1 regulation of metabotropic glutamate receptormediated neuronal excitability. J Neurosci 29:9977-9986. 